\title{
Review Article \\ RAR/RXR and PPAR/RXR Signaling in Spinal Cord Injury
}

\author{
Sabien van Neerven ${ }^{1,2}$ and Jörg Mey ${ }^{1,2}$ \\ ${ }^{1}$ Institute of Biology II, RWTH Aachen University, 52056 Aachen, Germany \\ ${ }^{2}$ EURON Graduate School of Neuroscience, 6229 Maastricht, The Netherlands
}

Correspondence should be addressed to Jörg Mey, mey@bio2.rwth-aachen.de

Received 23 December 2006; Accepted 28 February 2007

Recommended by Bradley Taylor

The retinoid acid receptors (RAR) and peroxisome proliferator-activated receptors (PPAR) have been implicated in the regulation of inflammatory reactions. Both receptor families contain ligand-activated transcription factors which form heterodimers with retinoid X receptors (RXR). We review data that imply RAR/RXR and PPAR/RXR pathways in physiological reactions after spinal cord injury. Experiments show how RAR signaling may improve axonal regeneration and modulate reactions of glia cells. While anti-inflammatory properties of PPAR are well documented in the periphery, their possible roles in the central nervous system have only recently become evident. Due to its anti-inflammatory function this transcription factor family promises to be a useful target after spinal cord or brain lesions.

Copyright (c) 2007 S. van Neerven and J. Mey. This is an open access article distributed under the Creative Commons Attribution License, which permits unrestricted use, distribution, and reproduction in any medium, provided the original work is properly cited.

\section{INTRODUCTION}

During the last decade much progress has been made disentangling the physiological responses after central nervous system (CNS) injury. Yet, there is still no effective treatment available to prevent the devastating effects that result from major CNS lesions. Although neurite sprouting and axonal growth is observed after spinal cord injury (SCI), successful regeneration beyond the lesion-induced scar does not occur. In contrast, axonal regeneration with functional recovery is possible in the peripheral nervous system (PNS). The different outcomes of CNS and PNS lesions are largely due to differences in the cellular and molecular signals that neurons encounter in these environments. Three important problems after CNS injury are (1) development of a growth inhibitory glial scar, (2) secondary neuronal and glial degeneration as a delayed consequence of the lesion, and (3) the failure of axonal regeneration in white matter tracts. Responding to these problems, most attention has been directed either to overcome the inhibitory barrier of the glial scar or to promote the growth of axon collaterals and thus compensate for permanently severed connections [1-3]. A subsidiary approach is to modify inflammatory reactions in order to limit the secondary degeneration. Synthetic corticosteroids, e.g., methylprednisolone, are the only pharmacological tools currently in clinical use [4]. In this review, we will discuss two nuclear re- ceptor families that have recently been discovered as possible therapeutic targets for the treatment of SCI and brain damage. Retinoic acid receptor (RAR) signaling may improve axonal regeneration, influence glial differentiation, and modulate inflammatory reactions [5]. Peroxisome proliferatoractivated receptors (PPAR) have a major function in antiinflammatory processes [6]. Both receptor classes, RAR and PPAR, heterodimerize with retinoid X receptors (RXR) to form active transcription factors.

\section{ENDOGENOUS RAR/RXR AND PPAR/RXR ACTIVITY IN THE INJURED NERVOUS SYSTEM}

\subsection{RAR/RXR signal transduction}

The RAR/RXR transcription factor complex is activated by ligand binding, its natural ligand being all-trans retinoic acid (all-trans RA). Retinoids are obtained from the diet in the form of vitamin A (retinol and retinal), retinyl esters, or $\beta$ carotene. Following cellular uptake of all-trans retinol from the plasma, the intracellular synthesis of retinoic acid occurs in two steps. (1) Retinol is oxidized to retinal, predominantly involving the alcohol dehydrogenases $\mathrm{ADH}-1,-3$, and -4. (2) The critical step is the subsequent oxidation of retinal to retinoic acid by retinaldehyde dehydrogenases (RALDH) [7]. Retinoic acid is released in a paracrine or autocrine fashion. The fact that RA activates nuclear transcription factors 
was discovered in 1987 [8, 9]. Retinoid receptors belong to the same superfamily as PPAR, thyroid hormone receptors (TR), and steroid receptors. They can be grouped into two families, the RARs and the RXRs, each consisting of three isoforms encoded by separate genes: $\operatorname{RAR} \alpha, \operatorname{RAR} \beta, \operatorname{RAR} \gamma$ (also: NR1B1-3) and $\operatorname{RXR} \alpha, \operatorname{RXR} \beta, \operatorname{RXR} \gamma(\mathrm{NR} 2 \mathrm{~B} 1-3)$. All-trans RA and 9-cis RA bind to the RAR family, whereas only 9-cis $\mathrm{RA}$ is a high-affinity ligand for the $\operatorname{RXR}[7,10]$. The active transcription factor complex consists of an RAR/RXR heterodimer, ligand, and coactivators. It interacts with retinoic acid response elements (RARE) in the promoters of target genes. About 500 genes have been suggested to be regulated by RAR/RXR signaling, however a much lower number was experimentally shown to be activated via the classical RARE driven pathway. Proven target genes include enzymes, transcription factors, cytokines, and cytokine receptors [5, 11]. In addition, many cases of gene suppression and nongenomic modes of action of RA and its receptors have been described [7].

\section{2. $R A R / R X R$ signaling after spinal cord injury}

The discovery that enzyme activity of a retinaldehyde dehydrogenase increased after spinal cord contusion injury was the first direct evidence that retinoids play a role in the physiological responses to SCI. Contusion injury caused a significant increase in RALDH2 enzyme activity, which peaked 8-14 days following the lesion [12]. While in the noninjured rat spinal cord RALDH2 is only present in the meninges, oligodendrocytes and in pericytes, around the lesion site, its immunoreactivity also appeared in a population of NG2-positive glia cells [13] (Figure 1(a)). NG2 is a chondroitin sulfate proteoglycan, expressed in cells that have been described as oligodendrocyte precursor cells, synantocytes or polydendrocytes. These cells respond to injury with increased production of NG2 and a subpopulation of them, close to the lesion site, appears to be involved in the local production of RA. Alternatively or additionally, RAsynthesizing cells migrate from the adjacent arachnoid membrane and from blood vessels toward the site of injury [13]. While only minor changes in the quantitative expression of retinoid receptors were observed after SCI, their cellular distribution changed remarkably (Figures 1(b), 1(c)). In the noninjured tissue, retinoid receptors were found in the cytosol of motorneurons and glia, but close to the injury site macrophages and surviving neurons displayed a nuclear localization of $\operatorname{RAR} \alpha, \operatorname{RXR} \alpha$, and $\operatorname{RXR} \beta$ [14]. In the context of locally rising RA synthesis, the observation that retinoid receptors translocate into the cell nuclei indicates that neurons, glia, and macrophages are targets of RA signaling after SCI. This interpretation is consistent with data on spinal cord development, where RA has been shown to be a regulator of cell differentiation [15-18].

\section{3. $R A R / R X R$ signaling after peripheral nerve injury}

RA signaling is implicated in the differentiation of neurons whose axons grow in the PNS, [19-22] and again in neurite regeneration $[23,24]$. Several mediators of the RA signaling pathway have been shown to be induced after peripheral nerve injury in the rat. Experimental lesion of the sciatic nerve induced expression of the cellular retinol binding protein-I (CRBP-I) [25], which is implicated in retinoid metabolism [26]. Similarly, transcript and protein concentrations of the cellular retinoic acid binding proteinII (CRABP-II) increased strongly [25]. CRABP-II is probably involved in the intracellular transport of RA to the cell nucleus [27]. As after SCI, the RA-synthesizing enzyme RALDH2 was present in the injured nerve. After sciatic nerve injury in transgenic reporter mice, local activation of RARE was detectable in the regenerating nerve, indicating that RA-dependent gene expression is induced during peripheral nerve regeneration [25]. The expression of retinoid receptors also changed significantly. Following sciatic nerve crush, mRNA of all RARs and of RXR $\alpha$ was increased, and at 4, 7, and 14 days after the injury protein levels of $\operatorname{RAR} \alpha, \operatorname{RAR} \beta$, and $\operatorname{RXR} \alpha$ were augmented [28]. To study Wallerian degeneration in the absence of axonal regeneration, the distal nerve segment can be cut off and sutured to the peroneus muscle. Under these conditions $\operatorname{RAR} \alpha$ and $\operatorname{RAR} \beta$ were upregulated in the degenerating nerve.

Cell culture experiments indicated that $\operatorname{RAR} \beta$ is required for RA-induced axonal regeneration [24]. Consequently, experiments with RAR $\beta$-deficient mice corroborated this interpretation because there were significantly less GAP43positive, regenerating axons after sciatic nerve crush in the knockout animals [29]. Since RALDH2 [23] and RAR $\beta$ [30] are induced by NGF, RA appears to act downstream of this neurotrophin. RA/RAR $\beta$ signaling seemed to be necessary for the neurotrophic activity of NGF [23]. In addition, neurotrophin-independent RA/RAR $\beta$ activity contributes to axon outgrowth [29]. Double labeling with cell type specific markers in the sciatic nerve demonstrated expression of retinoid receptors mostly in macrophages and Schwann cells. In cultured primary Schwann cells, RA downregulated CNTF [31] and raised expression of ErbB3, a neuregulin receptor that is necessary for normal myelination. Finally, RXR $\alpha$ labeling was shown to colocalize with some regenerating axons, indicative of a direct role for $\operatorname{RXR} \alpha$ in nerve regeneration [28].

\subsection{PPAR/RXR signal transduction}

Peroxisome proliferator-activated receptors belong to the same superfamily as the RAR. The first PPAR was discovered, cloned, and sequenced in 1990, and it was named after its property to be activated by drugs that cause proliferation of peroxisomes in hepatocytes [32]. Until now, three different isoforms of PPAR, encoded by separate genes, have been identified: $\operatorname{PPAR} \alpha$ (NR1C1), PPAR $\beta / \delta$ (NUC1, NR1C2), and PPAR $\gamma$ (NR1C3). The different isoforms have similar structural features, however each isoform exhibits its own specific tissue expression pattern and distinct physiological functions depending on ligand activation [33, 34]. PPAR also heterodimerize with RXR, then bind as a complex to their response elements (PPRE).These consist of 

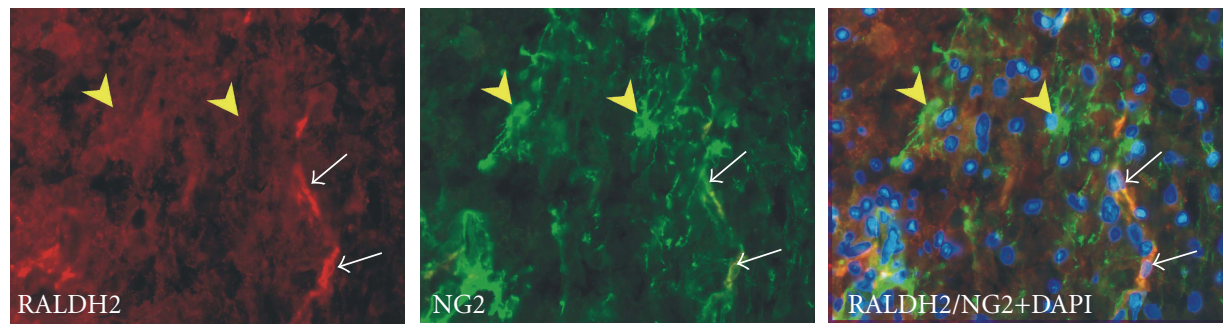

(a)
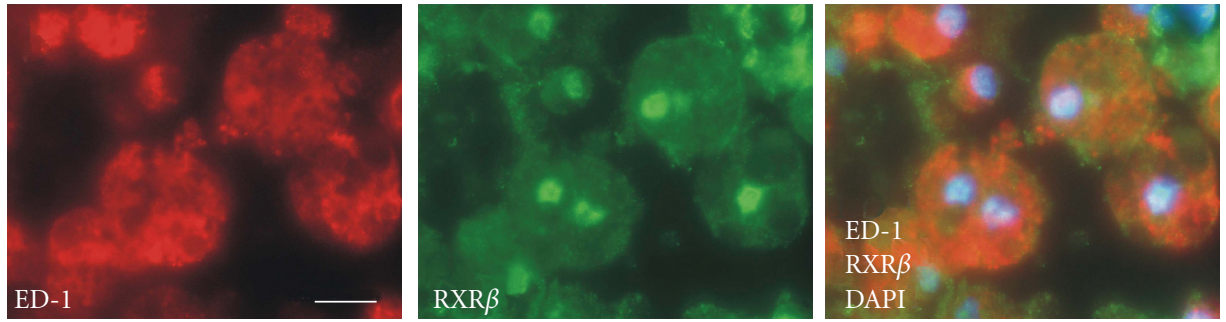

(b)
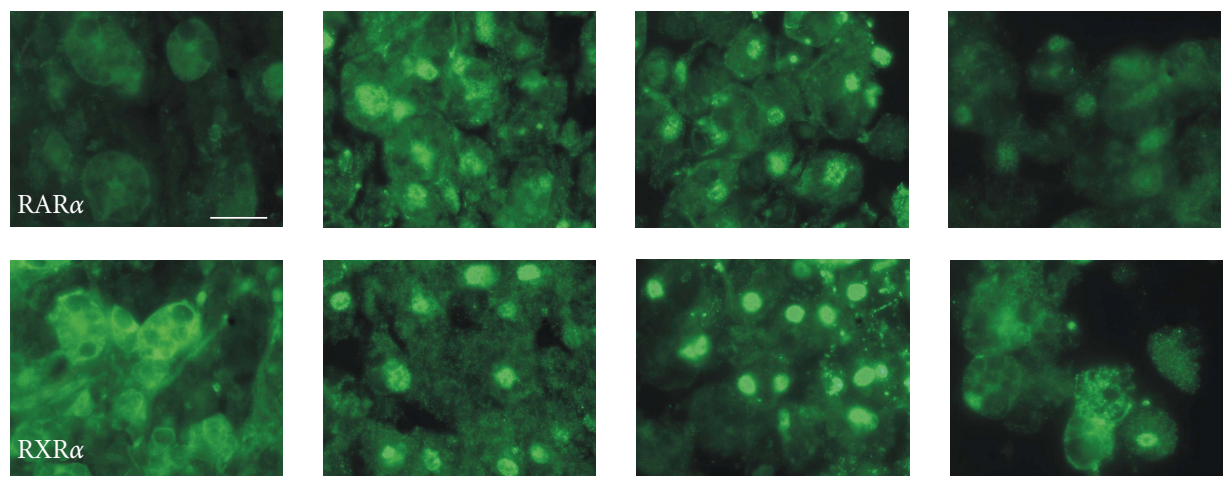

4 dpo

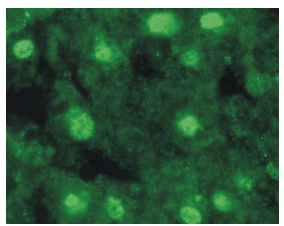

7 dpo

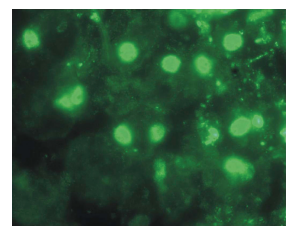

14 dpo

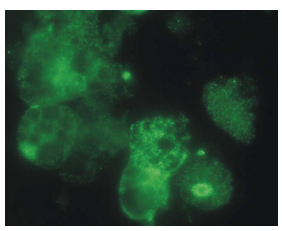

21 dpo

(c)

FIGURE 1: Retinoic acid synthesis and nuclear translocation of RAR/RXR after spinal cord injury. (a) Double immunostaining of rat spinal cord sections shows RALDH-2 immunoreactivity (red) in a subpopulation of NG2-positive glia (green) 7 days after contusion injury. RALDH2/NG2 expressing cells were only detected in the vicinity of the lesion site, many NG2 cells do not contain the RA-synthesizing enzyme (yellow arrow heads). White arrows point to DAPI-stained cell nuclei of RALDH2/NG2 cells in superimposed photographs. (b) At 7 dpo, ED1-positive macrophages at the lesion site express RXR $\beta$ in their cell nuclei. (c) SCI-induced transient translocation of RAR $\beta$ and RXR $\alpha$ from the cytosol into the nuclei of activated macrophages/microglia. All scale bars are $20 \mu m$ (sources: [12, 14]).

two repeats of the consensus sequence AGGTCA separated by one or two nucleotides (direct repeats DR-1 and DR-2) [35]. Natural ligands of PPAR are fatty acids, prostaglandins, and oxidized fatty acid derivatives. They are also activated by synthetic ligands like the lipid-lowering fibrates and the anti-diabetic glitazones [36]. PPAR, which have been implicated in lipid metabolism, cellular proliferation and inflammatory responses, are widely expressed, for example, in colon, spleen, retina, the cardiovascular system, liver, skeletal muscles, and in adipose tissue. Their expression by monocytes, dendritic cells, endothelial cells, megakaryocytes, and lymphocytes may be related to immune functions $[34,36]$. PPAR $y$ can also influence gene expression independently of PPRE. The activity of a number of transcription factors, for example, NF $\kappa$ B, AP-1, and STAT-1, are inhibited by PPAR $\gamma$ via direct interaction or by competition for limiting supplies of coactivators [6].

\subsection{PPAR/RXR signaling after spinal cord injury}

PPAR are expressed in the developing and adult CNS. PPAR $\alpha$ and $\operatorname{PPAR} \beta / \delta$, but not PPAR $\gamma$ were found in cervical, thoracic, and lumbar segments of the adult spinal cord, in the thalamus and cerebral cortex [37] (Figure 2). Immunohistochemical staining showed that $\operatorname{PPAR} \beta / \delta$ is the main isoform present in neuronal cell bodies of the spinal cord gray matter. Both receptors, $\operatorname{PPAR} \alpha$ and $\operatorname{PPAR} \beta / \delta$, were concentrated in cell nuclei. In the white matter PPAR $\alpha$ appeared particularly strong in $\operatorname{PPAR} \beta / \delta$-negative astrocytes, whereas oligodendrocytes expressed only $\operatorname{PPAR} \beta / \delta$ [38]. $\mathrm{PPAR} \beta / \delta$ is a factor in neuronal differentiation, and functions of this re- 
ceptor in various aspects of neural physiology have been suggested $[38,39]$. While in two studies PPAR $\gamma$ could not be detected in brain and spinal cord $[37,38]$, this receptor is expressed in microglial primary cultures [40] and may be upregulated after injury. In a different report, all PPAR and RXR were found immunohistochemically throughout the adult rat CNS [41].

Endogenous PPAR ligands may play a role in modulating the inflammatory response after SCI, possibly preventing the expansion of the initial damage. Genovese and coworkers [42] examined the effects of endogenous PPAR $\alpha$ ligands in an experimental model of spinal cord trauma. SCI was induced in wild-type and in PPAR $\alpha$-deficient $(-/-)$ mice. The injury resulted in severe trauma characterized by edema, loss of myelin, neutrophil infiltration, apoptosis, and increased production of TNF $\alpha$. Compared to wild-type animals, all these parameters were augmented in $\operatorname{PPAR} \alpha-/-$ mice. The absence of PPAR $\alpha$ also interfered with recovery of limb function [42]. Studies using animal models of chronic pain indicate that PPAR $\alpha$ is involved in the neural processing of pain $[43,44]$.

\section{REGULATION OF INFLAMMATORY PROCESSES BY RAR/RXR SIGNALING IN THE SPINAL CORD}

Although the inflammatory response limits the effects of a pathogenic insult, it is also responsible for most of the secondary damage incurred after spinal cord injury. The regulation of these events is therefore of primary therapeutic concern. Both pathways, RAR/RXR and PPAR/RXR signaling are implicated.

\subsection{Inflammatory reactions in the spinal cord}

The physiological events following spinal cord injury can be differentiated into an acute phase (the first 24hrs), followed by a subacute phase (24-72hrs), and a late phase (3-90 days). Events after this time are considered chronic. CNS injury directly leads to release of inflammatory signals resulting in the production of vasoactive mediators and chemotactic factors. Primary damage consists mainly of severed axons, neuronal and oligodendrocyte cell death. Expansion of the initial damage is then caused by a disruption of the blood supply and an extended inflammatory reaction. Depending on the type of injury, the blood-brain barrier is disrupted. This event determines the extent to which bloodderived cells participate in the inflammatory process $[45,46]$. When the blood-brain barrier breaks down, the release of cytokines and chemokines leads to a massive recruitment of inflammatory cells from the periphery, including hematogenous neutrophils and perivascular/meningeal macrophages. These cells contribute to tissue damage by the production of proteolytic enzymes and reactive oxygen species. Microglia and macrophages phagocytose dead or injured neurons and glia, and are responsible for the clearance of cellular debris [45].

Microglia, perivascular macrophages, and activated astrocytes are the most important local sources of cytokines.
Astrocytes are further involved in the formation of a glial scar, thereby insulating the healthy tissue from uncontrollable processes in the damaged area. Acute inflammation can develop into a chronic process when feedback mechanisms fail to inhibit amplification of the inflammatory response. Chronic inflammation leads to a continuous influx of neutrophils, macrophages, lymphocytes, and eosinophils from the circulation, causing more tissue destruction and scarring.

\section{2. $R A R / R X R$ signaling is involved in inflammation}

Before the molecular mechanisms of the retinoid signaling pathway were understood, anti-inflammatory properties of RA had already been described. In 1983, a study showed that oral administration of retinoids affected dermal inflammatory cells and reduced elevated skin temperature [47]. Retinoic acid has beneficial effects in diseases with an inflammatory-based pathology including asthma, arthritis, and atherosclerosis [48, 49]. A number of cell culture studies support the hypothesis that RA reduces inflammatory activation of monocytes, macrophages, myeloma cells, and polymorphonuclear cells (neutrophil granulocytes). Signals that were found to be downregulated by retinoids include IL- $1 \alpha$, IL- $1 \beta$, IL-6, TNF $\alpha$, IL-8, prostaglandin $\mathrm{E}_{2}$, production of reactive oxygen species, and release of lysosomal enzymes. A table with these effects and references is presented in [5]. In contrast to a majority of findings that indicate an anti-inflammatory role of RAR/RXR signaling, it was also reported that 9-cis RA induced secretion of MCP-1 and thereby stimulated monocyte migration [50]. In combination with T-cell stimulating agents, all-trans RA, 9-cis RA, and an RAR agonist, TTNPB, indirectly increased proliferation of human T lymphocytes and IL-2 secretion [51].

One of the major transcription factors responsible for the regulation of inflammatory cytokines is $\mathrm{NF} \kappa \mathrm{B}$. It was shown that RXR inhibits $\mathrm{NF} \kappa \mathrm{B}$-dependent gene expression (IL-12) [52]. In the experiments, interference of RXR with DNA binding of $N F \kappa B$ required the presence of the RXR ligand 9-cis RA. The negative RXR/NF $\kappa \mathrm{B}$ interaction appears to be mutual because increasing levels of transfection with $\mathrm{NF} \kappa \mathrm{B}$ subunits also abrogated expression of a retinoid reporter construct [52].

\subsection{The role of $R A R / R X R$ in inflammatory reactions after CNS injury}

Although retinoic acid has so far not been used to modify inflammatory reactions in the CNS in vivo, cell culture experiments demonstrate anti-inflammatory effects on microglia and astrocytes [5]. Primary cultures of microglia and astrocytes are most frequently prepared from cerebral cortex of perinatal rats and mice. One can expose these cultures to LPS to simulate a bacterial infection, or treat them with $\beta$-amyloid peptide $(\mathrm{A} \beta)$ to mimic the immunogenic stimulus of Alzheimer's disease. In this kind of experiment, RA treatment suppressed the induction of TNF $\alpha$ and iNOS. Effects correlated with enhanced expression of $\operatorname{RAR} \beta, \operatorname{TGF} \beta$, 


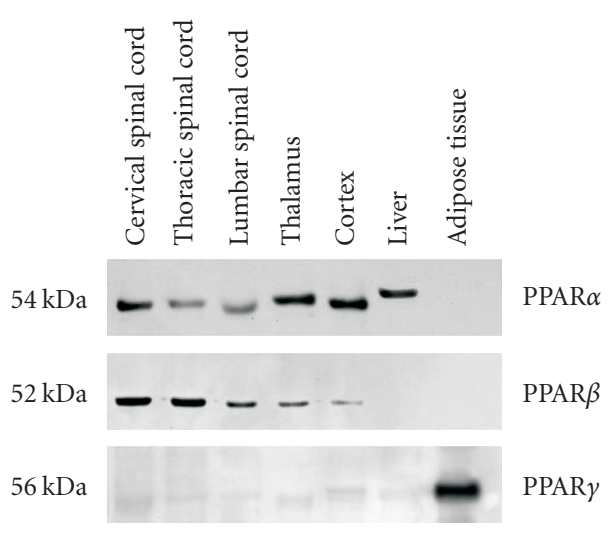

(a)
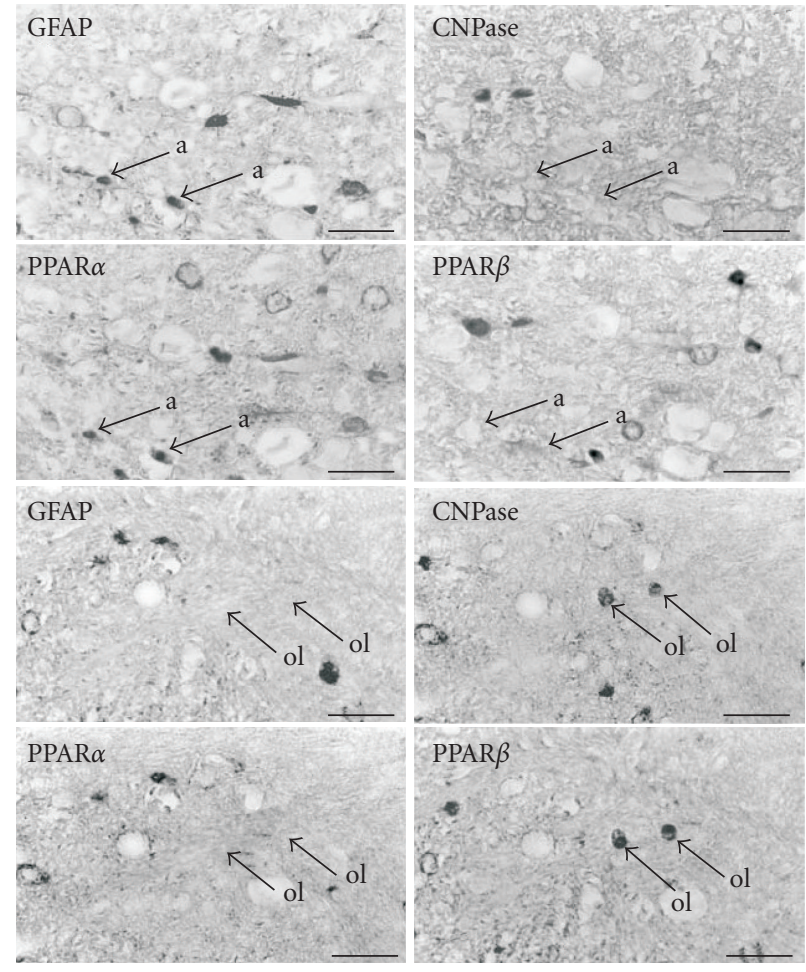

(b)

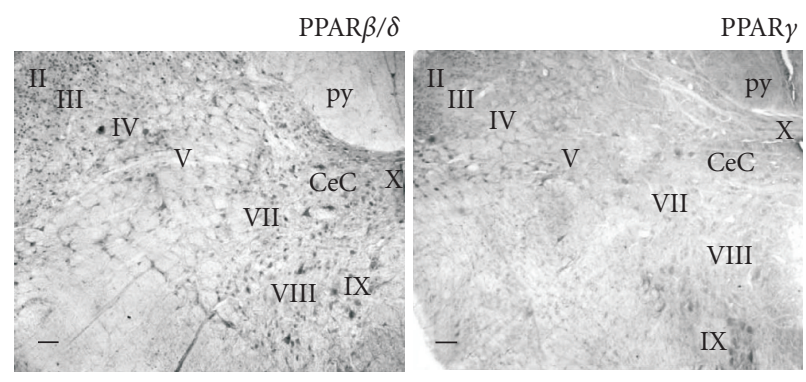

(c)

FIGURE 2: Localization of PPAR $\alpha$ and PPAR $\beta / \delta$ in astrocytes and oligodendrocytes in the spinal cord. (a) Western blotting shows PPAR $\alpha$ and PPAR $\beta$ but not PPAR $\gamma$ in spinal cord, telencephalon, and diencephalon. Identical expression patterns were detected with RT-PCR. (b) Detection of PPAR immunoreactive cells in the white matter of rat spinal cord. GFAP-positive/CNPase-negative astrocytes are immunoreactive for PPAR $\alpha$ (marked a, upper four panels) while GFAP-negative/CNPase-positive oligodendrocytes express PPAR $\beta$ (marked ol, lower panels) (scale bars: $25 \mu \mathrm{m}$, source: [38]). (c) Distribution of PPAR $\beta / \delta$ and PPAR $\gamma$ immunoreactive cells in the spinal cord of the adult rat (cervical level, coronal sections, scale bar: $100 \mu \mathrm{m}$, source: [41]).

and inhibition of $\mathrm{NF} \kappa \mathrm{B}$ nuclear translocation [53]. $\mathrm{Xu}$ and Drew demonstrated that 9-cis RA suppressed LPS-induced production of $\mathrm{NO}$ as well as of proinflammatory cytokines TNF $\alpha$, IL- $1 \beta$, and IL-12p40 in primary mouse microglia, while IL-6 secretion and MCP-1 production were not significantly affected (Figure 3) [54]. In astrocytes from rat brain and in C6 astroglioma cells, 9-cis RA and all-trans RA inhibited IFN $\gamma$-induced inflammatory responses [55].

Matrix metalloproteinases (MMP) are involved in the breakdown of the extracellular matrix and other proteins. These proteases are products of leukocytes and endothelial cells and are released in response to various cytokines and growth factors. Increased proteolytic activity of MMP can lead to disruption of the blood-brain barrier and escalate the inflammatory response $[56,57]$. Retinoic acid has negative effects on secretion and expression of these enzymes. It reduced mRNA, protein synthesis, and secretion of MMP-9 (gelatinase B) in lymphocytes from patients with chronic B-lymphocytic leukemia and in human monocytes [58]. Other metalloproteinases including MMP-1 and MMP-13 appeared to be influenced by RA as well [59]. 


\section{REGULATION OF INFLAMMATORY PROCESSES BY PPAR/RXR SIGNALING IN THE SPINAL CORD}

\subsection{PPAR/RXR signaling counteracts inflammatory processes}

For the PPAR family, anti-inflammatory effects are well documented. One mechanism involves direct interaction of PPAR with proinflammatory transcription factors, most importantly $\mathrm{NF} \kappa \mathrm{B}$ and $\mathrm{AP}-1$, and the subsequent reduction of gene transcription. This has been observed in vitro in human vascular endothelial cells [60], human aorta smooth muscle cells [61], in C2C12 skeletal muscle cells (in a model for insulin resistance in type 2 diabetes) [62], and in fibroblasts from rheumatoid arthritis patients [63]. PPAR knockout studies supplement and confirm these results. One of the first reports indicating that PPAR $\alpha$ is involved in attenuating inflammation demonstrated that the eicosanoid $\mathrm{LTB}_{4}$ binds and activates PPAR $\alpha$. Subsequently, PPAR $\alpha$ deficient mice were shown to have a prolonged inflammatory response when challenged with $\mathrm{LTB}_{4}$ or arachidonic acid [64].

An interaction of PPAR $\alpha$ with NF $\kappa$ B is indicated by studies of inflammatory cytokine production in aging. In aged mice, $\mathrm{NF} \kappa \mathrm{B}$ becomes constitutively active in many tissues due to oxidative stress, which eventually leads to the production of cytokines. Administration of PPAR $\alpha$ activators was found to restore the cellular redox balance, to suppress the constitutive activation of $\mathrm{NF} \kappa \mathrm{B}$ and to eliminate the spontaneous production of IL- 6 and IL-12 $[65,66]$. Other examples where PPAR $\alpha-/-$ mice suffer from more severe inflammatory reactions are carrageenan-induced hypersensitivity [67], airway inflammation [68], and experimental colitis [69]. On the molecular level, these investigations demonstrated Fas-ligand, IL- $1 \beta$, TNF $\alpha$, keratinocyte-derived chemokine, MIP-2, MCP-1, ICAM-1, and enzyme activities of MMP-9, myeloperoxidase, and iNOS to be influenced by PPAR $\alpha$ signaling $[67,69,70]$.

PPAR $\gamma$-deficient mice die in utero, but heterozygotic PPAR $\gamma+/-$ mice with $50 \%$ expression of the receptor survive and can be studied. In an investigation of PPAR $\gamma$ functions after intestinal and gastric ischemia/reperfusion injury, $\operatorname{PPAR} \gamma+/$ - mice displayed more severe lesions of the gastric intestinal mucosa. Treatment with the PPAR $\gamma$ ligand BRL49653 limited the damage of intestinal injury and resulted in downregulation of cell adhesion molecules and proinflammatory cytokines in the intestine and stomach $[71,72]$. As mentioned before, $\mathrm{NF} \kappa \mathrm{B}$ and inflammatory mediators are raised during the aging process. While this is accompanied by reduced PPAR $\gamma$ levels, the PPAR $\gamma$ ligand 2,4-TZD was shown to reduce age-related oxidative stress, the translocation of $\mathrm{NF} \kappa \mathrm{B}$ p 65 subunit to the nucleus and $\mathrm{NF} \kappa \mathrm{B}$-regulated transcription of iNOS, COX-2, IL- $1 \beta$, IL- 6 , and the cell-adhesion molecule VCAM-1 [73]. Another PPAR $\gamma$ agonist, rosiglitazone, relieved renal injury in a nephrotoxicity model, also acting via inhibiton of $\mathrm{NF} \kappa \mathrm{B}$ [74]. It seems therefore that both receptors PPAR $\alpha$ and PPAR $\gamma$ play a general role in mod- ulating the inflammatory response in a wide variety of tissues.

\subsection{Effect of PPAR activation on macrophages, microglia, and astrocytes}

Given that PPAR agonists influence peripheral macrophages [75], it was to be expected that they act on brain macrophages after disruption of the blood-brain barrier. PPAR $\alpha$ is already present in undifferentiated monocytes, while PPAR $y$ expression is induced during differentiation $[76,77]$ and upregulated in the course of macrophage activation [78-82]. A number of cell culture studies with macrophages and microglia demonstrate that agonists of $\operatorname{PPAR} \alpha$ and PPAR $\gamma$ elicit the same anti-inflammatory effects that we have discussed above. When cells were activated with bacterial antigens or $\mathrm{A} \beta$, the PPAR ligands typically prevented or reduced the inflammatory response. This effect was observed on the following levels: (1) activity of transcription factors NF $\kappa$ B, AP-1, and STAT-1, (2) secretion of proinflammatory cytokines and chemokines, (3) enzyme activities of COX-2, iNOS, and MMP-9, and (4) the formation of reactive oxigen radicals. A synopsis of these results is presented in Table 1.

Such effects were observed with natural ligands, for example, prostaglandins, with artificial PPAR activators, for example, antidiabetic thiadiazolidinones, and with nonsteroid anti-inflammatory drugs [83]. A very efficient endogenous agonist of PPAR $\gamma$ is the prostaglandin 15d-PGJ2 [70]. However, this drug also interferes with the transcriptional activity of NF $\kappa$ B independently of PPAR $\gamma$ activation because overexpression of PPAR $\gamma$ or an antagonist of PPAR $\gamma$ did not alter the 15d-PGJ2 effect on LPS/IFN $\gamma$-dependent inflammatory reaction. It was concluded that 15d-PGJ2 inhibits the inflammatory response by directly regulating the $\mathrm{NF} \kappa \mathrm{B}$ and $\mathrm{PI} 3 \mathrm{~K}-$ Akt pathways $[79,84]$.

With respect to microglia effects on nerve cells, PPAR activation with synthetic ligands can be neuroprotective. When cortical neurons were exposed to the cell-free supernatant from activated microglia, neurons survived better when microglia had also been incubated with PPAR $y$ agonists [85]. Some experiments in vivo also support this concept. Oral administration of pioglitazone or the nonsteroidal anti-inflammatory drug ibuprofen, which is also a ligand for $\operatorname{PPAR} \gamma$, reduced the number of activated microglia and reactive astrocytes in the hippocampus and cerebral cortex. This was observed in 10-month-old APPV717I mice, an inflammation model for Alzheimer's disease [83]. Pioglitazone protected mice also from MPTP-induced dopaminergic neuronal cell loss and mitigated inflammatory response by microglia in an animal model of Parkinson's disease [86].

As mentioned before, astrocytes participate in the secretion of cytokines and form a glial scar around the damaged tissue. Since the production of microglia primary cultures also involves isolation of astrocytes, it was a straightforward approach to test PPAR agonists on this type of glia as well (Figure 3) [87-89]. Results, which were generally in line with the anti-inflammatory effects on microglia, are also included in Table 1. 


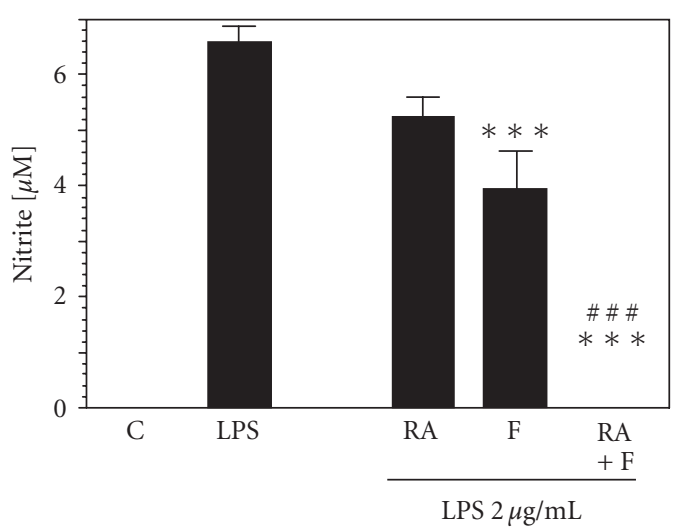

(a)

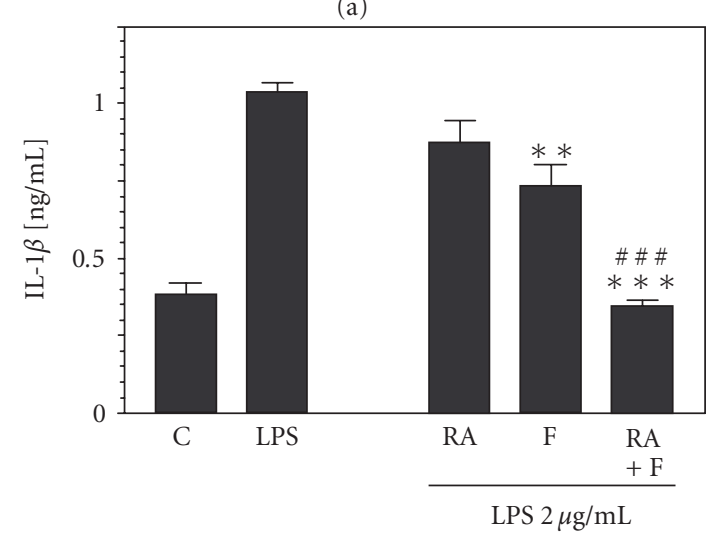

(c)

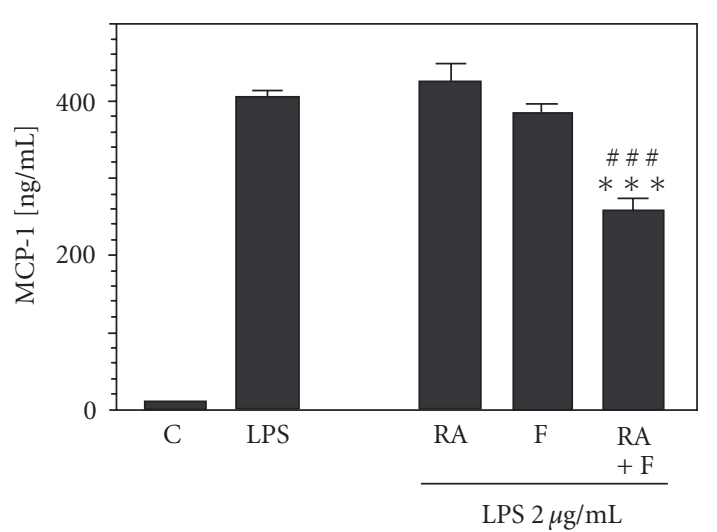

(b)

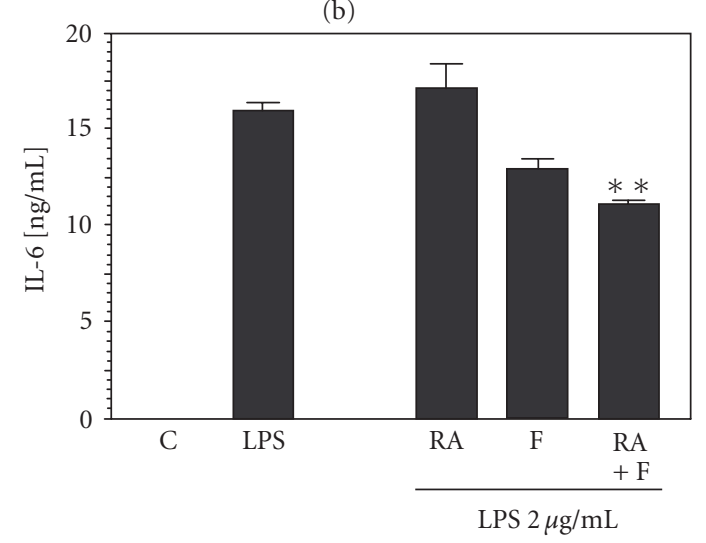

(d)

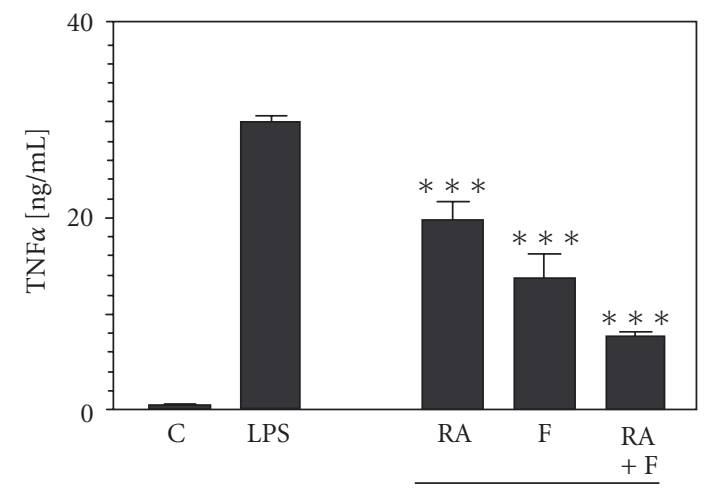

LPS $2 \mu \mathrm{g} / \mathrm{mL}$

(e)

FIGURE 3: Anti-inflammatory effects of PPAR and RAR agonists in astrocytes. Astrocyte primary cultures from cortices of newborn mice were treated with 9-cis RA (RA) and/or the PPAR $\alpha$ agonist fenofibrate (F) for 1hour and then stimulated with $2 \mu \mathrm{g} / \mathrm{mL}$ LPS for 24 hours. (a) Nitrite production as an indicator of NOS activity was reduced by $1 \mu M$ RA or $100 \mu M$ F, and completely suppressed with RA plus F. Pretreatment of RA and/or F also decreased the release of (b) the chemokine MCP-1 (RA: $2 \mu M$, F: $200 \mu M$ ), and cytokines (c) IL-1 $\beta$ (RA: $1 \mu M$, F: $100 \mu M$ ), (d) IL-6 (RA: $2 \mu M$, F: $50 \mu M$ ), and (e) TNF $\alpha$ (RA: $1 \mu M$, F: $100 \mu M$ ) in response to LPS. Cytokine production was measured with ELISA. Experiments with microglia cultures revealed similar effects, except for MCP-1, whose production was stimulated by 9-cis RA in microglia. Error bars indicate SEM, asterisks indicate significant differences compared to the LPS condition (sources: [54, 78]).

\section{APPLICATION OF RETINOIDS AND PPAR LIGANDS AFTER SPINAL CORD AND PERIPHERAL NERVE INJURY}

Retinoic acid is a well-characterized morphogenetic factor in embryonic development. Stem cells and several cell lines can be induced with RA to differentiate to a neuronal phenotype.
A number of experiments with developing sympathetic neurons and with sensory neurons from dorsal root ganglia revealed that RA has neurotrophic effects or induces neurite growth. The question arises whether these properties can be exploited to support axonal regeneration $[5,90]$. 


\subsection{Retinoic acid-induced axonal growth in vitro and in vivo}

While the most convincing demonstration that RA can act as an axon-guiding chemoattractant was recently published using the snail Lymnaea stagnalis [91], a number of earlier studies indicated that retinoids may fulfill similar functions in vertebrates. Neurites extending from chick neural tube cells responded to a gradient of RA [92]. Positive effects on axon outgrowth were also reported using explants from murine embryonic spinal cord [93], embryonic cerebellum [94], and amphibian spinal cord [95]. In a chick retinal explant assay, RA enhanced neurite outgrowth under the condition that the neurotrophin BDNF was subsequently added in vitro [96]. RA supported survival and morphological differentiation of cultured rat spinal cord neurons and increased neurite density. In this context, astrocytes were implicated as regulators of local RA concentration [16, 17].

Corcoran, Maden, and coworkers suggested that the loss of regeneration in the adult mammalian CNS is related to developmental changes in retinoid signaling. They observed that the RAR $\beta 2$ receptor, which is present when neurite outgrowth occurs from embryonic spinal cord explants, was not detectable in the adult spinal cord [97]. A supporting result was that specifically RAR $\beta$ mediated the induction of neurite outgrowth from subpopulations of sensory neurons [24]. In addition to the inhibitory glial environment [1], intrinsic changes in CNS neurons have been assumed to be responsible for the loss of regenerative ability during CNS development [98]. The declining expression of RAR $\beta 2$ may be one of those changes. To test this hypothesis, the RAR $\beta 2$ gene was transfected into spinal cord explants with a lentiviral vector. This treatment allowed the outgrowth of many neurites, implying the involvement of RAR $\beta 2$ in axonal regeneration [97]. Consequently, to demonstrate that a renewed expression of the appropriate receptor mechanism might induce axonal regeneration into the spinal cord in vivo, Wong and others [99] transfected RAR $\beta 2$ in adult rats. They then analyzed regeneration of sensory axons into the spinal cord and performed behavioral experiments. Following complete dorsal root transections by means of a crush injury, axons regenerated across the dorsal root entry zone into the CNS. Both myelinated and nonmyelinated fibers were found to have grown in the spinal cord where they projected into the gray matter, formed functional connections and improved sensorimotor recovery of the animals [99]. In another study, artificially induced RAR $\beta 2$ expression also supported regeneration of descending corticospinal tract fibers after midcervical spinal cord injury (Figure 4). Again, the induced regeneration of fibers was accompanied by improved sensory and locomotor behavior [100]. These data suggest not only that $\operatorname{RAR} \beta$ is involved in activating a physiological program of regeneration but also that retinoic acid signaling may be used as a therapeutic tool in spinal cord injury.

\subsection{Manipulation of RAR/RXR signaling in the peripheral nervous system}

As mentioned above, it has been known for some time that retinoids act as neurotrophic factors for sympathetic and sensory neurons of the peripheral nervous system [20-24]. However, very few studies have addressed the role of RA in peripheral nerve regeneration in vivo. Taha and coworkers tested whether local RA injections improved morphological and functional regeneration of tibial nerves undergoing anastomosis. They showed that animals injected locally with RA exhibited increased axonal density when compared to vehicle-treated animals [101]. Several cell culture experiments suggested that RA effects may involve an upregulation of neurotrophin receptors, and molecular studies indicate mutually synergistic influences of the RA- and neurotrophin-signaling pathways. Nerve growth factor induced the RA-synthesizing enzyme RALDH in dorsal root ganglia [23] and activated the RAR $\beta$ promoter [30]. RA, on the other hand, caused expression of various neurotrophin receptors (see $[5,90]$ for review). That synergistic interactions between RA and neurotrophins take place in vivo was revealed in a study using a mouse model for diabetes [102]. Treatment of the animals with all-trans RA via subcutaneous injection in a dose of $20 \mathrm{mg} / \mathrm{kg}$ was able to prevent the NGF depletion normally seen in diabetic mice. Microscopic analysis subsequently showed that diabetes-associated loss of Schwann cells, of myelinated, and of nonmyelinated axons was strongly reduced by RA. This beneficial effect was also measurable in behavioral tests of sensory-motor functions [102].

\subsection{Retinoids and PPAR ligands in pain signaling}

In a different line of research about spinal cord sensitization, some contrasting results were obtained recently. To investigate whether retinoids might be involved in the processing of nociceptive information, especially in situations of hyperalgesia due to inflammation, rats were given 10$15 \mathrm{mg} / \mathrm{kg}$ all-trans RA orally for 4 days. Electrophysiological recordings revealed that treated animals had decreased thresholds to mechanical and electrical stimulation of the paws and increased cutaneous receptive fields. This increased responsiveness caused by RA was similar to hyperalgesia induced by intraplantar administration of carrageenan (which leads to local inflammation) [103]. On the molecular level, RA induced changes of gene expression in the spinal cord, for instance, an increase of COX-2 and IL-1. Inhibition of these pathways with IL-1 receptor antagonist and the COXinhibitor dexketoprofen reduced responses to mechanical or thermal stimulation when those had been sensitized with RA [104]. In these studies, it was concluded that all-trans RA induced changes in the spinal cord that are similar to inflammation. At this point, it is difficult to reconcile this conclusion with the anti-inflammatory properties when RA was combined with stimuli of bacterial infection or $\mathrm{A} \beta$ deposition.

In contrast to RA, administration of the PPAR $\alpha$ agonists GW7647, Wy14643, perfluorooctanoic acid, and PEA reduced nocifensive behaviors in various animal models of hyperalgesia, implicating a mitigating role of PPAR in the regulation of pain signaling $[43,44]$. GW7647 and PEA also prevented firing of spinal cord nociceptive neurons in rats after peripheral exposure to formalin[44]. 


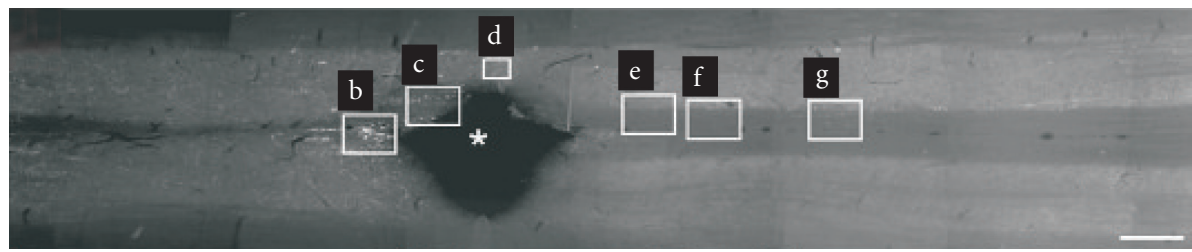

(a)

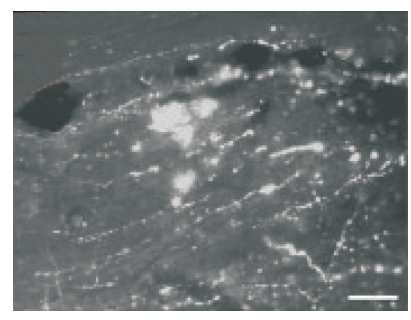

(b)

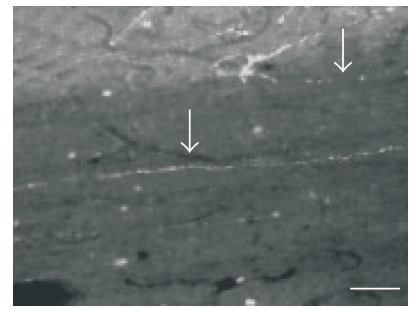

(e)

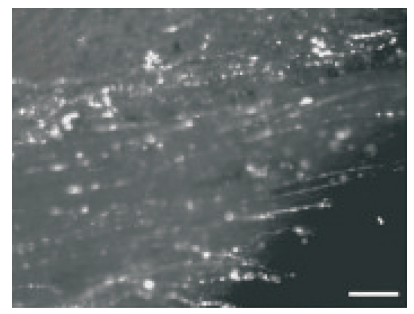

(c)

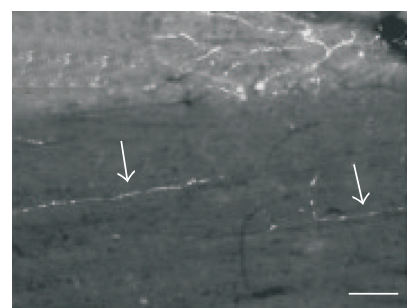

(f)

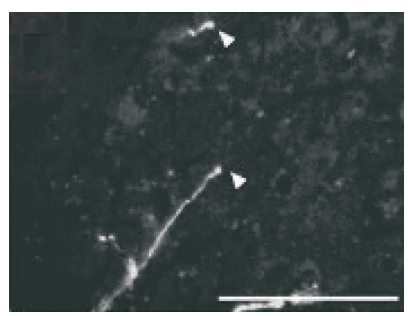

(d)

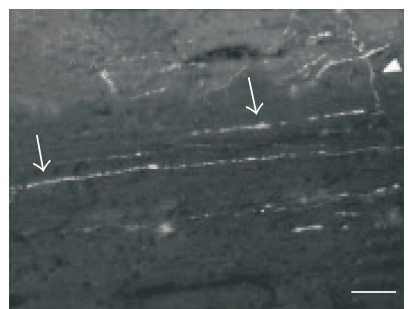

(g)

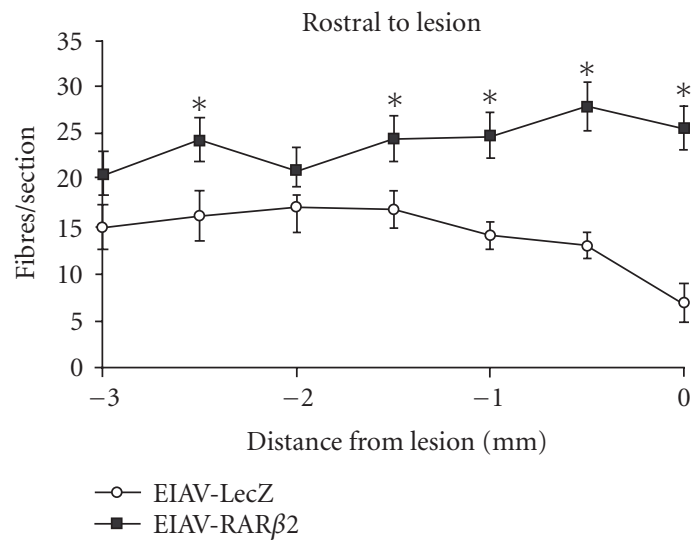

(h)

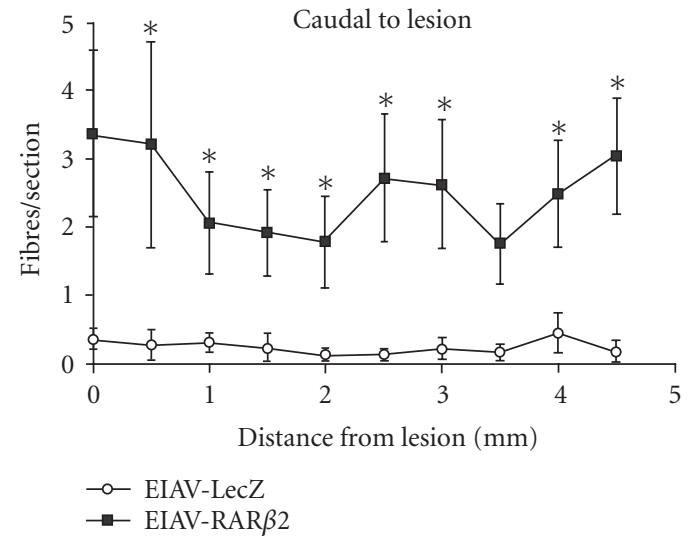

(i)

FIgURE 4: Transfection of RAR $\beta$ induces regeneration of corticospinal axons in vivo. (a) Longitudinal sections of the adult rat spinal cord were traced with BDA to determine fibre regeneration in the corticospinal tract; overview of the lesion site in an animal injected with the RAR $\beta 2$ expressing construct (EIAV-RAR $\beta 2$, Rostral: left). (b) Animals with RAR $\beta 2$-transfected cells displayed less fiber degeneration than control rats. (c) Labeled axons were detected up to the edge of the lesion, (d) at the distal edge of the lesion, and (e-g) at various distances caudal to the lesion. Growth cone-like endings were detected at the tips of some axons (white arrowheads in d). Axons appear to send collaterals (white arrowhead in g) from white matter to grey matter. (Scale bars in (a): 1mm, in (b-g): 100 $\mu m$.) (h-i) Quantification of BDA-labeled fibres in the corticospinal tract after spinal cord lesion. EIAV-RAR $\beta 2$-treated animals displayed increased fiber numbers rostral and caudal to the lesion compared to control animals $(P<.05$, two-way ANOVA) (source: $[100])$.

\subsection{Use of PPAR ligands as anti-inflammatory treatment after spinal cord injury}

The knowledge about anti-inflammatory properties of PPAR ligands obtained in cell cultures soon prompted animal experiments. In these, $\operatorname{PPAR} \alpha$ ligands were indeed shown to exert neuroprotective effects after traumatic brain injury [105]. Recently, it was discovered that synthetic PPAR $\gamma$ ligands rosiglitazone and pioglitazone are also neuroprotective by reducing the inflammation in the spinal cord. Treatment of rats directly after SCI resulted in a decreased lesion site, better survival of motor neurons, sparing of myelin, reduced 
TABLE 1: Anti-inflammatory effects of PPAR $\alpha$ and PPAR $\gamma$ agonists on the molecular level.

\begin{tabular}{|c|c|c|c|}
\hline Experimental system & Nuclear receptor & Regulated signals & Reference \\
\hline Cytokine- and LPS-stimulated microglia & $\operatorname{PPAR} \alpha, \mathrm{RXR}$ & NO synthesis, IL- $1 \beta$, IL-6, IL-12p 40, TNF $\alpha$, MCP- 1 & {$[78]$} \\
\hline Activated macrophages & $\operatorname{PPAR} \alpha, \gamma$ & iNOS, heme ogygenase (COX-2, HSP70 not affected) & {$[70]$} \\
\hline Activated macrophages & $\operatorname{PPAR} \gamma$ & iNOS, MMP-9, scavenger receptor A & {$[80]$} \\
\hline Activated human monocytes & $\operatorname{PPAR} \gamma$ & IL- $1 \beta$, IL-6, TNF $\alpha$ & {$[81]$} \\
\hline Activated macrophages & $\operatorname{PPAR} \gamma$ & Reactive oxigen species & {$[77]$} \\
\hline LPS-stimulated microglia & $\operatorname{PPAR} \gamma$ & IL- $1 \beta$, IL-6, TNF $\alpha$, MCP- 1 , iNOS & {$[87]$} \\
\hline LPS-stimulated microglia & $\operatorname{PPAR} \gamma$ & IL-6, TNF $\alpha$, iNOS, COX-2 & {$[85]$} \\
\hline $\mathrm{A} \beta$-stimulated microglia & $\operatorname{PPAR} \gamma$ & IL-6, TNF $\alpha$, COX-2 & {$[82]$} \\
\hline LPS-stimulated astrocytes & $\operatorname{PPAR} \alpha, \mathrm{RXR}$ & IL- $1 \beta$, IL-6, TNF $\alpha$, iNOS, MCP-1 & {$[88]$} \\
\hline LPS-stimulated astrocytes & $\operatorname{PPAR} \gamma$ & IL-6, TNF $\alpha$, iNOS, COX-2 & {$[85]$} \\
\hline LPS-stimulated astrocytes & $\operatorname{PPAR} \gamma$ & IL- $1 \beta$, IL-6, TNF $\alpha$, MCP-1, iNOS & {$[87]$} \\
\hline Cerebellar injection of IFN $\gamma$, LPS & $\operatorname{PPAR} \gamma$ & iNOS, cell death & {$[89]$} \\
\hline MPTP-treated mice & $\operatorname{PPAR} \gamma$ & iNOS, I $\kappa \mathrm{B}$, cell death & {$[86]$} \\
\hline APPV717I transgenic mice & $\operatorname{PPAR} \gamma$ & iNOS, COX-2, $\beta$-amyloid & {$[83]$} \\
\hline Rat spinal cord injury & $\operatorname{PPAR} \gamma$ & IRF-1, IL- $1 \beta$, IL-6, MCP-1, ICAM, Egr-1 & {$[106]$} \\
\hline Rat model for stroke & $\operatorname{PPAR} \gamma$ & IL- $1 \beta$, iNOS, COX-2 & {$[107]$} \\
\hline
\end{tabular}

astrogliosis, and less microglial activation. These features were accompanied by enhanced functional motor recovery and reduced hyperalgesia [106]. Investigation of gene expression revealed that pioglitazone lowered levels of transcription factors IRF-1, NF $\kappa$ B, transmembrane proteins Egr1, ICAM, and cytokine/chemokines IL- $1 \beta$, IL-6, MCP-1, but increased expression of neuroprotective genes and antioxidant enzymes. In a rat model for stroke (middle cerebral artery occlusion), PPAR $\gamma$ ligands were able to improve neurological outcome, decreased infarct size, and reduced inflammation. Fewer microglia/macrophages appeared to be present, and transcript and protein levels of IL-1, COX-2, and iNOS were also lower [107].

\section{CONCLUSION}

The studies discussed here demonstrate that RAR/RXR and PPAR/RXR signaling may be therapeutic targets after spinal cord injury. The main potential of PPAR ligands derives from their anti-inflammatory capacity, which has been corroborated in rodent models of inflammation involving various peripheral organs. After spinal cord injury, inflammatory reactions account for a large proportion of the secondary damage to neurons and oligodendrocytes. In this context, first experiments show that PPAR ligands are neuroprotective. Since PPAR activators are already in use to treat diabetes, clinical studies after stoke or other kinds of CNS damage are to be expected. While retinoids also have anti-inflammatory properties, they exert more direct effects on the nerve tissue. In several populations of neurons, axonal regeneration can be induced or supported by the activation of RAR/RXR signaling. Since systemic application of retinoic acid influences neural physiology within the CNS, therapeutic possibilities arise here as well. As in the case of cancer treatment, an important consideration is the expression of retinoid receptors. After spinal cord injury the induction of RAR $\beta$ appears to be a re- quirement. In addition to the classical transcriptional effects, retinoids and PPAR ligands can act via receptor-independent mechanisms. This, however, is a largely uncharted territory where therapeutic benefits remain to be discovered.

\section{ABBREVIATIONS}

A $\beta$ : $\quad$ Beta amyloid peptide

ADH: Alcohol dehydrogenase

AP: $\quad$ Activating protein

BDA: Biotinylated dextran amine

BDNF: Brain-derived neurotrophic factor

CNS: Central nervous system

CNTF: Ciliary neurotrophic factor

COX: Cyclooxygenase

CRABP: Cellular retinoic acid binding protein

CRBP: Cellular retinol binding protein

dpo: dies post operationem

EGF: Epidermal growth factor

Egr: EGF receptor

ErbB: Tyrosine kinase related to the EGF recaptor

GAP43: Growth associated protein 43

ICAM: Intercellular cell adhesion molecule

IFN: Interferon, IL-interleukin

iNOS: Inducible NO synthase

IRF: Interferon regulatory factor

LPS: Lipopolysaccharide

$\mathrm{LTB}_{4}$ : Leukotriene B4

MCP: Macrophage chemoattractant protein 


$\begin{array}{ll}\text { MIP: } & \text { Macrophage inflammatory protein } \\ \text { MMP: } & \text { Matrix metalloproteinase } \\ \text { MPTP: } & \text { 1-methyl-4-phenyl-1,2,3,6- } \\ & \text { tetrahydropyridine } \\ \text { NF } \kappa \text { B: } & \text { Nuclear factor } \kappa \text { B } \\ & \text { NGF Nerve growth factor } \\ \text { NR(plus number): } & \text { Nuclear receptor } \\ \text { PEA: } & \text { Palmitoyl ethanolamide } \\ \text { 15d-PGJ2: } & \text { 15-deoxy-delta prostaglandin J2 } \\ \text { PI3-K: } & \text { Phosphoinositide 3-kinase } \\ \text { PNS: } & \text { Peripheral nervous system } \\ \text { PPAR: } & \text { Peroxisome proliferator-activated } \\ & \text { receptor } \\ \text { PPRE: } & \text { PPAR response element } \\ \text { RA: } & \text { Retinoic acid } \\ \text { RALDH: } & \text { Retinaldehyde dehydrogenase } \\ \text { RAR: } & \text { Retinoic acid receptor } \\ \text { RARE: } & \text { Retinoic acid response element } \\ \text { RXR: } & \text { Retinoid X receptor } \\ \text { SCI: } & \text { Spinal cord injury } \\ \text { STAT: } & \text { Signal transducer and activator of } \\ \text { TGF: } & \text { transcription } \\ \text { TNF: } & \text { Transforming growth factor } \\ \text { TR: } & \text { Tumor necrosis factor } \\ \text { TTNPB: } & \text { Thyroid hormone receptor } \\ & \text { 4-[(E)-2-(5,6,7,8-tetrahydro- } \\ & \text { 5,5,8,8-tetramethyl-2- } \\ \text { 2,4-TZD: } & \text { naphthalenyl)-1-propenyl] } \\ \text { VCAM: } & \text { 2,4-thiazolidinedione } \\ & \text { Vascular cell adhesion molecule } \\ & \end{array}$

\section{ACKNOWLEDGMENTS}

S. van Neerven is supported by a Marie Curie Fellowship of the EURON Graduate School of Neuroscience. The authors thank Eric Kampmann for helpful discussions and proofreading of the manuscript.

\section{REFERENCES}

[1] J. Silver and J. H. Miller, "Regeneration beyond the glial scar," Nature Reviews Neuroscience, vol. 5, no. 2, pp. 146-156, 2004.

[2] C. M. Liberto, P. J. Albrecht, L. M. Herx, V. W. Yong, and S. W. Levison, "Pro-regenerative properties of cytokine-activated astrocytes," Journal of Neurochemistry, vol. 89, no. 5, pp. 1092-1100, 2004.

[3] M. Makwana and G. Raivich, "Molecular mechanisms in successful peripheral regeneration," FEBS Journal, vol. 272, no. 11, pp. 2628-2638, 2005.

[4] D. C. Baptiste and M. G. Fehlings, "Pharmacological approaches to repair the injured spinal cord," Journal of Neurotrauma, vol. 23, no. 3-4, pp. 318-334, 2006.

[5] J. Mey, "New therapeutic target for CNS injury? The role of retinoic acid signaling after nerve lesions," Journal of Neurobiology, vol. 66, no. 7, pp. 757-779, 2006.

[6] T. Kielian and P. D. Drew, "Effects of peroxisome proliferatoractivated receptor- $\gamma$ agonists on central nervous system inflammation," Journal of Neuroscience Research, vol. 71, no. 3, pp. 315-325, 2003.
[7] R. Blomhoff and H. K. Blomhoff, "Overview of retinoid metabolism and function," Journal of Neurobiology, vol. 66, no. 7, pp. 606-630, 2006.

[8] V. Giguere, E. S. Ong, P. Segui, and R. M. Evans, "Identification of a receptor for the morphogen retinoic acid," Nature, vol. 330, no. 6149, pp. 624-629, 1987.

[9] M. Petkovich, N. J. Brand, A. Krust, and P. Chambon, "A human retinoic acid receptor which belongs to the family of nuclear receptors," Nature, vol. 330, no. 6147, pp. 444-450, 1987.

[10] J. Bastien and C. Rochette-Egly, "Nuclear retinoid receptors and the transcription of retinoid-target genes," Gene, vol. 328, no. 1-2, pp. 1-16, 2004.

[11] M. A. Lane and S. J. Bailey, "Role of retinoid signalling in the adult brain," Progress in Neurobiology, vol. 75, no. 4, pp. 275293, 2005.

[12] J. Mey, D. J. Morassutti, G. Brook, et al., "Retinoic acid synthesis by a population of NG2-positive cells in the injured spinal cord," European Journal of Neuroscience, vol. 21, no. 6, pp. 1555-1568, 2005.

[13] J. Kern, K. Schrage, G. C. Koopmans, E. A. Joosten, P. McCaffery, and J. Mey, "Characterization of retinaldehyde dehydrogenase-2 induction in NG2-positive glia after spinal cord contusion injury," International Journal of Developmental Neuroscience, vol. 25, no. 1, pp. 7-16, 2007.

[14] K. Schrage, G. Koopmans, E. A. J. Joosten, and J. Mey, "Macrophages and neurons are targets of retinoic acid signaling after spinal cord contusion injury," European Journal of Neuroscience, vol. 23, no. 2, pp. 285-295, 2006.

[15] S. Sockanathan, T. Perlmann, and T. M. Jessell, "Retinoid receptor signaling in postmitotic motor neurons regulates rostrocaudal positional identity and axonal projection pattern," Neuron, vol. 40, no. 1, pp. 97-111, 2003.

[16] L. Wuarin and N. Sidell, "Differential susceptibilities of spinal cord neurons to retinoic acid-induced survival and differentiation," Developmental Biology, vol. 144, no. 2, pp. 429-435, 1991.

[17] L. Wuarin, N. Sidell, and J. de Vellis, "Retinoids increase perinatal spinal cord neuronal survival and astroglial differentiation," International Journal of Developmental Neuroscience, vol. 8, no. 3, pp. 317-326, 1990.

[18] J. Vermot, B. Schuhbaur, H. Le Mouellic, et al., "Retinaldehyde dehydrogenase 2 and Hoxc 8 are required in the murine brachial spinal cord for the specification on Lim1+ motoneurons and the correct distribution of Islet1+ motoneurons," Development, vol. 132, no. 7, pp. 1611-1621, 2005.

[19] J.-P. Liu, E. Laufer, and T. M. Jessell, “Assigning the positional identity of spinal motor neurons: rostrocaudal patterning of Hox-c expression by FGFs, Gdf11, and retinoids," Neuron, vol. 32, no. 6, pp. 997-1012, 2001.

[20] A. V. Holst, F. Lefcort, and H. Rohrer, "TrkA expression levels of sympathetic neurons correlate with NGF-dependent survival during development and after treatment with retinoic acid," European Journal of Neuroscience, vol. 9, no. 10, pp. 2169-2177, 1997.

[21] S. Wyatt, R. Andres, H. Rohrer, and A. M. Davies, "Regulation of neurotrophin receptor expression by retinoic acid in mouse sympathetic neuroblasts," Journal of Neuroscience, vol. 19, no. 3, pp. 1062-1071, 1999.

[22] A. Rodriguez-Tebar and H. Rohrer, "Retinoic acid induces NGF-dependent survival response and high-affinity NGF receptors in immature chick sympathetic neurons," Development, vol. 112, no. 3, pp. 813-820, 1991. 
[23] J. Corcoran and M. Maden, "Nerve growth factor acts via retinoic acid synthesis to stimulate neurite outgrowth," $\mathrm{Na}$ ture Neuroscience, vol. 2, no. 4, pp. 307-308, 1999.

[24] J. Corcoran, B. Shroot, J. Pizzey, and M. Maden, "The role of retinoic acid receptors in neurite outgrowth from different populations of embryonic mouse dorsal root ganglia," Journal of Cell Science, vol. 113, no. 14, pp. 2567-2574, 2000.

[25] N. Zhelyaznik, K. Schrage, P. McCaffery, and J. Mey, "Activation of retinoic acid signalling after sciatic nerve injury: upregulation of cellular retinoid binding proteins," European Journal of Neuroscience, vol. 18, no. 5, pp. 1033-1040, 2003.

[26] O. V. Belyaeva, O. V. Korkina, A. V. Stetsenko, T. Kim, P. S. Nelson, and N. Y. Kedishvili, "Biochemical properties of purified human retinol dehydrogenase 12 (RDH12): catalytic efficiency toward retinoids and $\mathrm{C}_{9}$ aldehydes and effects of cellular retinol-binding protein type I (CRBPI) and cellular retinaldehyde-binding protein (CRALBP) on the oxidation and reduction of retinoids," Biochemistry, vol. 44, no. 18, pp. 7035-7047, 2005.

[27] A. S. Budhu and N. Noy, "Direct channeling of retinoic acid between cellular retinoic acid-binding protein II and retinoic acid receptor sensitizes mammary carcinoma cells to retinoic acid-induced growth arrest," Molecular and Cellular Biology, vol. 22, no. 8, pp. 2632-2641, 2002.

[28] N. Zhelyaznik and J. Mey, "Regulation of retinoic acid receptors $\alpha, \beta$ and retinoid $\mathrm{X}$ receptor $\alpha$ after sciatic nerve injury," Neuroscience, vol. 141, no. 4, pp. 1761-1774, 2006.

[29] P.-L. So, P. K. Yip, S. Bunting, et al., "Interactions between retinoic acid, nerve growth factor and sonic hedgehog signalling pathways in neurite outgrowth," Developmental Biology, vol. 298, no. 1, pp. 167-175, 2006.

[30] J. M. Cosgaya and A. Aranda, "Nerve growth factor activates the RAR $\beta 2$ promoter by a Ras-dependent mechanism," Journal of Neurochemistry, vol. 76, no. 3, pp. 661-670, 2001.

[31] V. Johann, N. Jeliaznik, K. Schrage, and J. Mey, "Retinoic acid downregulates the expression of ciliary neurotrophic factor in rat Schwann cells," Neuroscience Letters, vol. 339, no. 1, pp. 13-16, 2003.

[32] I. Issemann and S. Green, "Activation of a member of the steroid hormone receptor superfamily by peroxisome proliferators," Nature, vol. 347, no. 6294, pp. 645-650, 1990.

[33] S. A. Kliewer, B. M. Forman, B. Blumberg, et al., "Differential expression and activation of a family of murine peroxisome proliferator-activated receptors," Proceedings of the National Academy of Sciences of the United States of America, vol. 91, no. 15, pp. 7355-7359, 1994.

[34] B. P. Kota, T. H.-W. Huang, and B. D. Roufogalis, "An overview on biological mechanisms of PPARs," Pharmacological Research, vol. 51, no. 2, pp. 85-94, 2005.

[35] P. Gervois, S. Chopin-Delannoy, A. Fadel, et al., "Fibrates increase human REV-ERB $\alpha$ expression in liver via a novel peroxisome proliferator-activated receptor response element," Molecular Endocrinology, vol. 13, no. 3, pp. 400-409, 1999.

[36] L. A. Moraes, L. Piqueras, and D. Bishop-Bailey, "Peroxisome proliferator-activated receptors and inflammation," Pharmacology and Therapeutics, vol. 110, no. 3, pp. 371-385, 2006.

[37] O. Braissant and W. Wahli, "Differential expression of peroxisome proliferator-activated receptor- $\alpha,-\beta$, and $-\gamma$ during rat embryonic development," Endocrinology, vol. 139, no. 6, pp. 2748-2754, 1998.

[38] A. Benani, P. Krémarik-Bouillaud, A. Bianchi, P. Netter, A. Minn, and M. Dauça, "Evidence for the presence of both peroxisome proliferator-activated receptors alpha and beta in the rat spinal cord," Journal of Chemical Neuroanatomy, vol. 25, no. 1, pp. 29-38, 2003.

[39] A. Cimini, E. Benedetti, L. Cristiano, et al., "Expression of peroxisome proliferator-activated receptors (PPARs) and retinoic acid receptors (RXRs) in rat cortical neurons," Neuroscience, vol. 130, no. 2, pp. 325-337, 2005.

[40] A. Bernardo, G. Levi, and L. Minghetti, "Role of the peroxisome proliferator-activated receptor- $\gamma$ (PPAR- $\gamma$ ) and its natural ligand 15-deoxy- $\Delta^{12,14}$-prostaglandin $\mathrm{J}_{2}$ in the regulation of microglial functions," European Journal of Neuroscience, vol. 12, no. 7, pp. 2215-2223, 2000.

[41] S. Moreno, S. Farioli-Vecchioli, and M. P. Cerù, "Immunolocalization of peroxisome proliferator-activated receptors and retinoid X receptors in the adult rat CNS," Neuroscience, vol. 123, no. 1, pp. 131-145, 2004.

[42] T. Genovese, E. Mazzon, R. Di Paola, et al., "Role of endogenous ligands for the peroxisome proliferators activated receptors alpha in the secondary damage in experimental spinal cord trauma," Experimental Neurology, vol. 194, no. 1, pp. 267-278, 2005.

[43] B. K. Taylor, N. Dadia, C. B. Yang, S. Krishnan, and M. Badr, "Peroxisome proliferator-activated receptor agonists inhibit inflammatory edema and hyperalgesia," Inflammation, vol. 26, no. 3, pp. 121-127, 2002.

[44] J. LoVerme, R. Russo, G. La Rana, et al., "Rapid broadspectrum analgesia through activation of peroxisome proliferator-activated receptor- $\alpha$," Journal of Pharmacology and Experimental Therapeutics, vol. 319, no. 3, pp. 10511061, 2006.

[45] G. Raivich, M. Bohatschek, C. U. A. Kloss, A. Werner, L. L. Jones, and G. W. Kreutzberg, "Neuroglial activation repertoire in the injured brain: graded response, molecular mechanisms and cues to physiological function," Brain Research Reviews, vol. 30, no. 1, pp. 77-105, 1999.

[46] P. G. Popovich, S. Stuckman, I. E. Gienapp, and C. C. Whitacre, "Alterations in immune cell phenotype and function after experimental spinal cord injury," Journal of Neurotrauma, vol. 18, no. 9, pp. 957-966, 2001.

[47] C. E. Orfanos and R. Bauer, "Evidence for anti-inflammatory activities of oral synthetic retinoids: experimental findings and clinical experience," British Journal of Dermatology, vol. 109, supplement 25, pp. 55-60, 1983.

[48] H. Fang, H. Jin, and H. Wang, "Effect of all-trans retinoic acid on airway inflammation in asthmatic rats and its mechanism," Journal of Huazhong University of Science and Technology-Medical Science, vol. 24, no. 3, pp. 229-232, 2004.

[49] Y. Nozaki, T. Yamagata, M. Sugiyama, S. Ikoma, K. Kinoshita, and M. Funauchi, "Anti-inflammatory effect of all-transretinoic acid in inflammatory arthritis," Clinical Immunology, vol. 119, no. 3, pp. 272-279, 2006.

[50] L. Zhu, C. L. Bisgaier, M. Aviram, and R. S. Newton, "9-cis retinoic acid induces monocyte chemoattractant protein-1 secretion in human monocytic THP-1 cells," Arteriosclerosis, Thrombosis, and Vascular Biology, vol. 19, no. 9, pp. 21052111, 1999.

[51] A. Ertesvag, N. Engedal, S. Naderi, and H. K. Blomhoff, "Retinoic acid stimulates the cell cycle machinery in normal T cells: involvement of retinoic acid receptor-mediated IL-2 secretion," Journal of Immunology, vol. 169, no. 10, pp. 55555563, 2002.

[52] S.-Y. Na, B. Y. Kang, S. W. Chung, et al., "Retinoids inhibit interleukin-12 production in macrophages through physical 
associations of retinoid X receptor and NF $\kappa \mathrm{B}$," Journal of Biological Chemistry, vol. 274, no. 12, pp. 7674-7680, 1999.

[53] S. T. Dheen, Y. Jun, Z. Yan, S. S. W. Tay, and E. A. Ling, "Retinoic acid inhibits expression of TNF- $\alpha$ and iNOS in activated rat microglia," GLIA, vol. 50, no. 1, pp. 21-31, 2005.

[54] J. Xu and P. D. Drew, "9-cis-retinoic acid suppresses inflammatory responses of microglia and astrocytes," Journal of Neuroimmunology, vol. 171, no. 1-2, pp. 135-144, 2006.

[55] W.-H. Choi, K.-A. Ji, S.-B. Jeon, et al., "Anti-inflammatory roles of retinoic acid in rat brain astrocytes: suppression of interferon- $\gamma$-induced JAK/STAT phosphorylation," Biochemical and Biophysical Research Communications, vol. 329, no. 1, pp. 125-131, 2005.

[56] L. J. Noble, F. Donovan, T. Igarashi, S. Goussev, and Z. Werb, "Matrix metalloproteinases limit functional recovery after spinal cord injury by modulation of early vascular events," Journal of Neuroscience, vol. 22, no. 17, pp. 7526-7535, 2002.

[57] S. Mun-Bryce and G. A. Rosenberg, "Gelatinase B modulates selective opening of the blood-brain barrier during inflammation," American Journal of Physiology, vol. 274, no. 5 part 2, pp. R1203-R1211, 1998.

[58] J. Nguyen, J. Dumont, and B. Bauvois, "Comparative effects of interferon-gamma and all-trans retinoic acid on secreted and surface-associated matrix metalloproteinase-9 expression of human monocytes," Cellular and Molecular Biology, vol. 52, no. 1, pp. 51-58, 2006.

[59] L.-J. Ho, L.-C. Lin, L.-F. Hung, et al., "Retinoic acid blocks pro-inflammatory cytokine-induced matrix metalloproteinase production by down-regulating JNK-AP-1 signaling in human chondrocytes," Biochemical Pharmacology, vol. 70, no. 2, pp. 200-208, 2005.

[60] P. Delerive, F. Martin-Nizard, G. Chinetti, et al., "Peroxisome proliferator-activated receptor activators inhibit thrombininduced endothelin-1 production in human vascular endothelial cells by inhibiting the activator protein-1 signaling pathway," Circulation Research, vol. 85, no. 5, pp. 394-402, 1999.

[61] P. Delerive, K. De Bosscher, S. Besnard, et al., "Peroxisome proliferator-activated receptor $\alpha$ negatively regulates the vascular inflammatory gene response by negative cross-talk with transcription factors NF- $\kappa \mathrm{B}$ and AP-1," Journal of Biological Chemistry, vol. 274, no. 45, pp. 32048-32054, 1999.

[62] M. Jové, J. C. Laguna, and M. Vázquez-Carrera, "Agonistinduced activation releases peroxisome proliferator-activated receptor $\beta / \delta$ from its inhibition by palmitate-induced nuclear factor- $\kappa \mathrm{B}$ in skeletal muscle cells," Biochimica et Biophysica Acta, vol. 1734, no. 1, pp. 52-61, 2005.

[63] H. Okamoto, T. Iwamoto, S. Kotake, S. Momohara, H. Yamanaka, and N. Kamatani, "Inhibition of NK- $\kappa$ B signaling by fenofibrate, a peroxisome proliferator-activated receptor- $\alpha$ ligand, presents a therapeutic strategy for rheumatoid arthritis," Clinical and Experimental Rheumatology, vol. 23, no. 3, pp. 323-330, 2005.

[64] P. R. Devchand, H. Keller, J. M. Peters, M. Vazquez, F. J. Gonzalez, and W. Wahli, "The PPAR $\alpha$-leukotriene $\mathrm{B}_{4}$ pathway to inflammation control," Nature, vol. 384, no. 6604, pp. 39-43, 1996.

[65] N. F. L. Spencer, M. E. Poynter, S.-Y. Im, and R. A. Daynes, "Constitutive activation of NF- $\kappa \mathrm{B}$ in an animal model of aging," International Immunology, vol. 9, no. 10, pp. 1581-1588, 1997.

[66] M. E. Poynter and R. A. Daynes, "Peroxisome proliferatoractivated receptor $\alpha$ activation modulates cellular redox status, represses nuclear factor- $\kappa \mathrm{B}$ signaling, and reduces in- flammatory cytokine production in aging," Journal of Biological Chemistry, vol. 273, no. 49, pp. 32833-32841, 1998.

[67] S. Cuzzocrea, E. Mazzon, R. Di Paola, et al., "The role of the peroxisome proliferator-activated receptor- $\alpha$ (PPAR- $\alpha$ ) in the regulation of acute inflammation," Journal of Leukocyte Biology, vol. 79, no. 5, pp. 999-1010, 2006.

[68] C. Delayre-Orthez, J. Becker, I. Guenon, et al., "PPAR $\alpha$ downregulates airway inflammation induced by lipopolysaccharide in the mouse," Respiratory Research, vol. 6, no. 1, p. 91, 2005.

[69] S. Cuzzocrea, R. Di Paola, E. Mazzon, et al., "Role of endogenous and exogenous ligands for the peroxisome proliferators activated receptors alpha (PPAR- $\alpha$ ) in the development of inflammatory bowel disease in mice," Laboratory Investigation, vol. 84, no. 12, pp. 1643-1654, 2004.

[70] P. R. Colville-Nash, S. S. Qureshi, D. Willis, and D. A. Willoughby, "Inhibition of inducible nitric oxide synthase by peroxisome proliferator-activated receptor agonists: correlation with induction of heme oxygenase 1," Journal of Immunology, vol. 161, no. 2, pp. 978-984, 1998.

[71] A. Nakajima, K. Wada, H. Miki, et al., "Endogenous PPAR $\gamma$ mediates anti-inflammatory activity in murine ischemiareperfusion injury," Gastroenterology, vol. 120, no. 2, pp. 460469, 2001.

[72] K. Wada, A. Nakajima, H. Takahashi, et al., "Protective effect of endogenous PPAR $\gamma$ against acute gastric mucosal lesions associated with ischemia-reperfusion," American Journal of Physiology - Gastrointestinal and Liver Physiology, vol. 287, no. 2, pp. G452-G458, 2004.

[73] B. Sung, S. Park, B. P. Yu, and H. Y. Chung, "Amelioration of age-related inflammation and oxidative stress by PPAR $\gamma$ activator: suppression of NF- $\kappa$ B by 2,4-thiazolidinedione," Experimental Gerontology, vol. 41, no. 6, pp. 590-599, 2006.

[74] S. Lee, W. Kim, S.-O. Moon, et al., "Rosiglitazone ameliorates cisplatin-induced renal injury in mice," Nephrology Dialysis Transplantation, vol. 21, no. 8, pp. 2096-2105, 2006.

[75] A. C. Li and W. Palinski, "Peroxisome proliferator-activated receptors: how their effects on macrophages can lead to the development of a new drug therapy against atherosclerosis," Annual Review of Pharmacology and Toxicology, vol. 46, pp. 1-39, 2006.

[76] G. Chinetti, S. Griglio, M. Antonucci, et al., "Activation of proliferator-activated receptors $\alpha$ and $\gamma$ induces apoptosis of human monocyte-derived macrophages," Journal of Biological Chemistry, vol. 273, no. 40, pp. 25573-25580, 1998.

[77] A. von Knethen and B. Brüne, "Delayed activation of PPAR $\gamma$ by LPS and IFN- $\gamma$ attenuates the oxidative burst in macrophages," FASEB Journal, vol. 15, no. 2, pp. 535-544, 2001.

[78] J. Xu, P. D. Storer, J. A. Chavis, M. K. Racke, and P. D. Drew, "Agonists for the peroxisome proliferator-activated receptor$\alpha$ and the retinoid $\mathrm{X}$ receptor inhibit inflammatory responses of microglia," Journal of Neuroscience Research, vol. 81, no. 3, pp. 403-411, 2005.

[79] T. V. Petrova, K. T. Akama, and L. J. Van Eldik, "Cyclopentenone prostaglandins suppress activation of microglia: down-regulation of inducible nitric-oxide synthase by 15 -deoxy- $\Delta^{12,14}$-prostaglandin $\mathrm{J}_{2}$," Proceedings of the $\mathrm{Na}$ tional Academy of Sciences of the United States of America, vol. 96, no. 8, pp. 4668-4673, 1999.

[80] M. Ricote, A. C. Li, T. M. Willson, C. J. Kelly, and C. K. Glass, "The peroxisome proliferator-activated receptor- $\gamma$ is a negative regulator of macrophage activation," Nature, vol. 391, no. 6662, pp. 79-82, 1998. 
[81] C. Jiang, A. T. Ting, and B. Seed, "PPAR- $\gamma$ agonists inhibit production of monocyte inflammatory cytokines," Nature, vol. 391, no. 6662, pp. 82-86, 1998.

[82] C. K. Combs, D. E. Johnson, J. C. Karlo, S. B. Cannady, and G. E. Landreth, "Inflammatory mechanisms in Alzheimer's disease: inhibition of $\beta$ - amyloid-stimulated proinflammatory responses and neurotoxicity by PPAR $\gamma$ agonists," Journal of Neuroscience, vol. 20, no. 2, pp. 558-567, 2000.

[83] M. T. Heneka, M. Sastre, L. Dumitrescu-Ozimek, et al., "Acute treatment with the PPAR $\gamma$ agonist pioglitazone and ibuprofen reduces glial inflammation and $A \beta 1-42$ levels in APPV717I transgenic mice," Brain, vol. 128, no. 6, pp. 1442 1453, 2005.

[84] S. Giri, R. Rattan, A. K. Singh, and I. Singh, "The 15-deoxy$\delta 12,14$-prostaglandin $\mathrm{J}_{2}$ inhibits the inflammatory response in primary rat astrocytes via down-regulating multiple steps in phosphatidylinositol 3-kinase-akt-NF- $\kappa$ B-p300 pathway independent of peroxisome proliferator-activated receptor $\gamma$," Journal of Immunology, vol. 173, no. 8, pp. 5196-5208, 2004.

[85] R. Luna-Medina, M. Cortes-Canteli, M. Alonso, A. Santos, A. Martínez, and A. Perez-Castillo, "Regulation of inflammatory response in neural cells in vitro by thiadiazolidinones derivatives through peroxisome proliferator-activated receptor $\gamma$ activation," Journal of Biological Chemistry, vol. 280, no. 22, pp. 21453-21462, 2005.

[86] T. Dehmer, M. T. Heneka, M. Sastre, J. Dichgans, and J. B. Schulz, "Protection by pioglitazone in the MPTP model of Parkinson's disease correlates with $\mathrm{I} \kappa \mathrm{B} \alpha$ induction and block of NFkB and iNOS activation," Journal of Neurochemistry, vol. 88, no. 2, pp. 494-501, 2004.

[87] P. D. Storer, J. Xu, J. Chavis, and P. D. Drew, "Peroxisome proliferator-activated receptor-gamma agonists inhibit the activation of microglia and astrocytes: implications for multiple sclerosis," Journal of Neuroimmunology, vol. 161, no. 1-2, pp. 113-122, 2005.

[88] J. Xu, J. A. Chavis, M. K. Racke, and P. D. Drew, "Peroxisome proliferator-activated receptor- $\alpha$ and retinoid X receptor agonists inhibit inflammatory responses of astrocytes," Journal of Neuroimmunology, vol. 176, no. 1-2, pp. 95-105, 2006.

[89] M. T. Heneka, T. Klockgether, and D. L. Feinstein, "Peroxisome proliferator-activated receptor- $\gamma$ ligands reduce neuronal inducible nitric oxide synthase expression and cell death in vivo," Journal of Neuroscience, vol. 20, no. 18, pp. 6862-6867, 2000.

[90] M. Clagett-Dame, E. M. McNeill, and P. D. Muley, "Role of all-trans retinoic acid in neurite outgrowth and axonal elongation," Journal of Neurobiology, vol. 66, no. 7, pp. 739-756, 2006.

[91] J. M. Dmetrichuk, R. L. Carlone, and G. E. Spencer, "Retinoic acid induces neurite outgrowth and growth cone turning in invertebrate neurons," Developmental Biology, vol. 294, no. 1, pp. 39-49, 2006.

[92] M. Maden, G. Keen, and G. E. Jones, "Retinoic acid as a chemotactic molecule in neuronal development," International Journal of Developmental Neuroscience, vol. 16, no. 5, pp. 317-322, 1998.

[93] S. D. P. Quinn and U. De Boni, "Enhanced neuronal regeneration by retinoic acid of murine dorsal root ganglia and of fetal murine and human spinal cord in vitro," In Vitro Cellular and Developmental Biology - Animal, vol. 27, no. 1, pp. 55-62, 1991.

[94] M. Yamamoto, P. McCaffery, and U. C. Dräger, "Influence of the choroid plexus on cerebellar development: analysis of retinoic acid synthesis," Developmental Brain Research, vol. 93, no. 1-2, pp. 182-190, 1996.

[95] K. Hunter, M. Maden, D. Summerbell, U. Eriksson, and N. Holder, "Retinoic acid stimulates neurite outgrowth in the amphibian spinal cord," Proceedings of the National Academy of Sciences of the United States of America, vol. 88, no. 9, pp. 3666-3670, 1991.

[96] J. Mey and N. Rombach, "Retinoic acid increases BDNFdependent regeneration of chick retinal ganglion cells in vitro," NeuroReport, vol. 10, no. 17, pp. 3573-3577, 1999.

[97] J. Corcoran, P.-L. So, R. D. Barber, et al., "Retinoic acid receptor $\beta_{2}$ and neurite outgrowth in the adult mouse spinal cord in vitro," Journal of Cell Science, vol. 115, no. 19, pp. 37793786, 2002.

[98] J. Mey and S. Thanos, "Ontogenetic changes in the regenerative ability of chick retinal ganglion cells as revealed by organ explants," Cell and Tissue Research, vol. 264, no. 2, pp. 347355, 1991.

[99] L.-F. Wong, P. K. Yip, A. Battaglia, et al., "Retinoic acid receptor $\beta_{2}$ promotes functional regeneration of sensory axons in the spinal cord," Nature Neuroscience, vol. 9, no. 2, pp. 243250, 2006.

[100] P. K. Yip, L.-F. Wong, D. Pattinson, et al., "Lentiviral vector expressing retinoic acid receptor $\beta_{2}$ promotes recovery of function after corticospinal tract injury in the adult rat spinal cord," Human Molecular Genetics, vol. 15, no. 21, pp. 31073118, 2006.

[101] M. O. Taha, M. Rosseto, M. M. Fraga, et al., "Effect of retinoic acid on tibial nerve regeneration after anastomosis in rats: histological and functional analyses," Transplantation Proceedings, vol. 36, no. 2, pp. 404-408, 2004.

[102] O. Arrieta, R. García-Navarrete, S. Zúñiga, et al., "Retinoic acid increases tissue and plasma contents of nerve growth factor and prevents neuropathy in diabetic mice," European Journal of Clinical Investigation, vol. 35, no. 3, pp. 201-207, 2005.

[103] E. A. Romero-Sandoval, C. Molina, M. Alique, V. MorenoManzano, F. J. Lucio, and J. F. Herrero, "Vitamin A active metabolite, all-trans retinoic acid, induces spinal cord sensitization. I. Effects after oral administration," British Journal of Pharmacology, vol. 149, no. 1, pp. 56-64, 2006.

[104] M. Alique, F. J. Lucio, and J. F. Herrero, "Vitamin A active metabolite, all-trans retinoic acid, induces spinal cord sensitization. II. Effects after intrathecal administration," British Journal of Pharmacology, vol. 149, no. 1, pp. 65-72, 2006.

[105] V. C. Besson, X. R. Chen, M. Plotkine, and C. MarchandVerrecchia, "Fenofibrate, a peroxisome proliferator-activated receptor $\alpha$ agonist, exerts neuroprotective effects in traumatic brain injury," Neuroscience Letters, vol. 388, no. 1, pp. 7-12, 2005.

[106] S.-W. Park, J.-H. Yi, G. Miranpuri, et al., “Thiazolidinedione class of peroxisome proliferator-activated receptor $\gamma$ agonists prevents neuronal damage, motor dysfunction, myelin loss, neuropathic pain, and inflammation after spinal cord injury in adult rats," Journal of Pharmacology and Experimental Therapeutics, vol. 320, no. 3, pp. 1002-1012, 2007.

[107] S. Sundararajan, J. L. Gamboa, N. A. Victor, E. W. Wanderi, W. D. Lust, and G. E. Landreth, "Peroxisome proliferatoractivated receptor- $\gamma$ ligands reduce inflammation and infarction size in transient focal ischemia," Neuroscience, vol. 130, no. 3, pp. 685-696, 2005. 


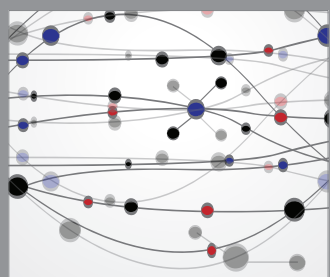

The Scientific World Journal
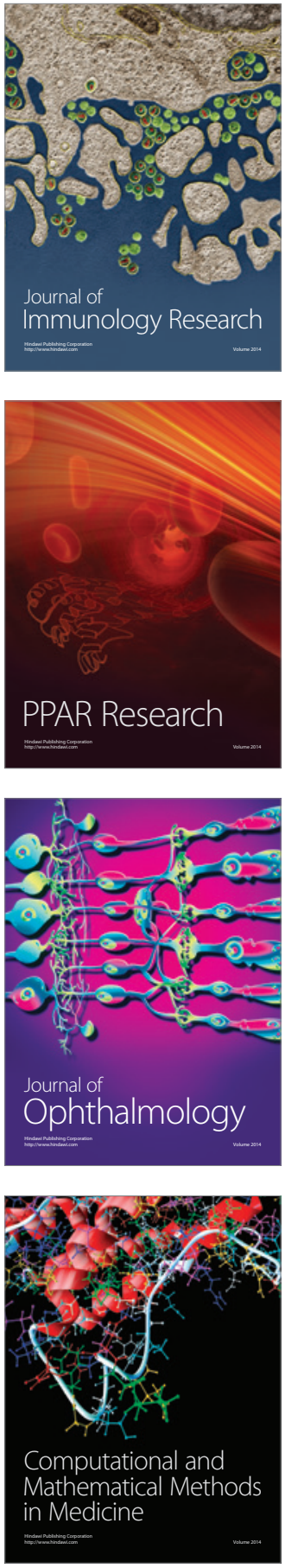

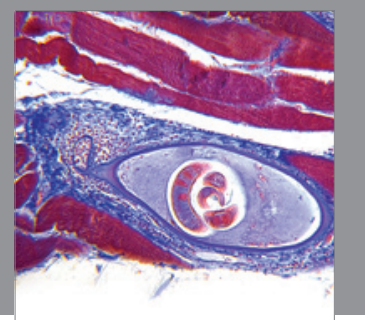

Gastroenterology

Research and Practice
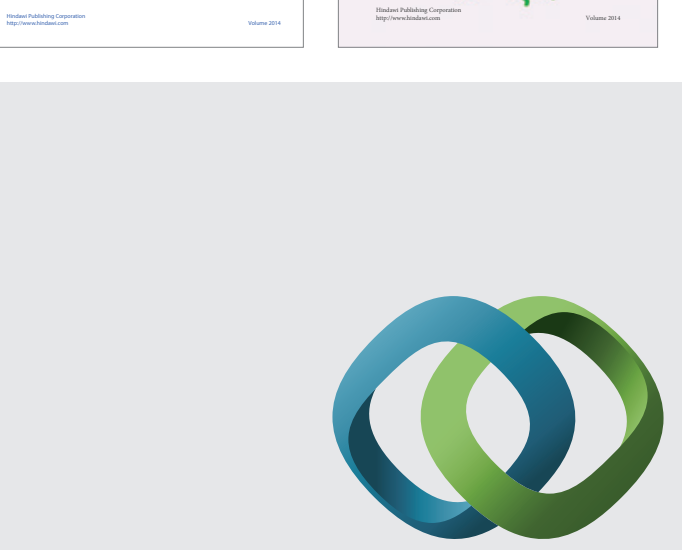

\section{Hindawi}

Submit your manuscripts at

http://www.hindawi.com
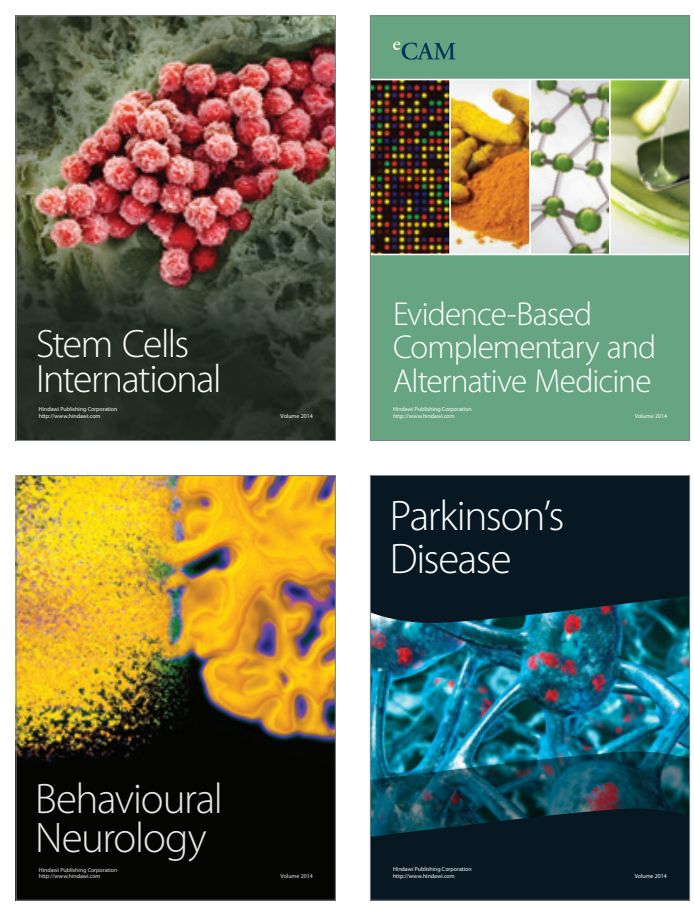

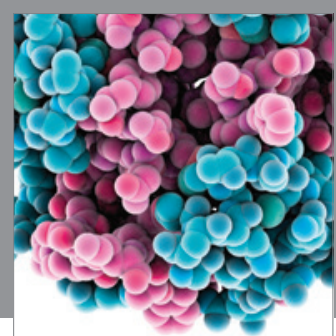

Journal of
Diabetes Research

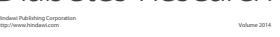

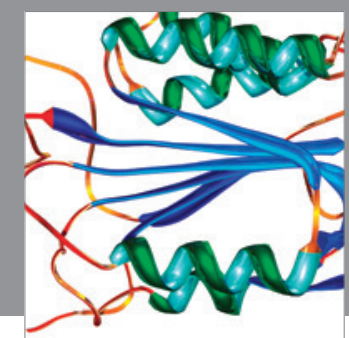

Disease Markers
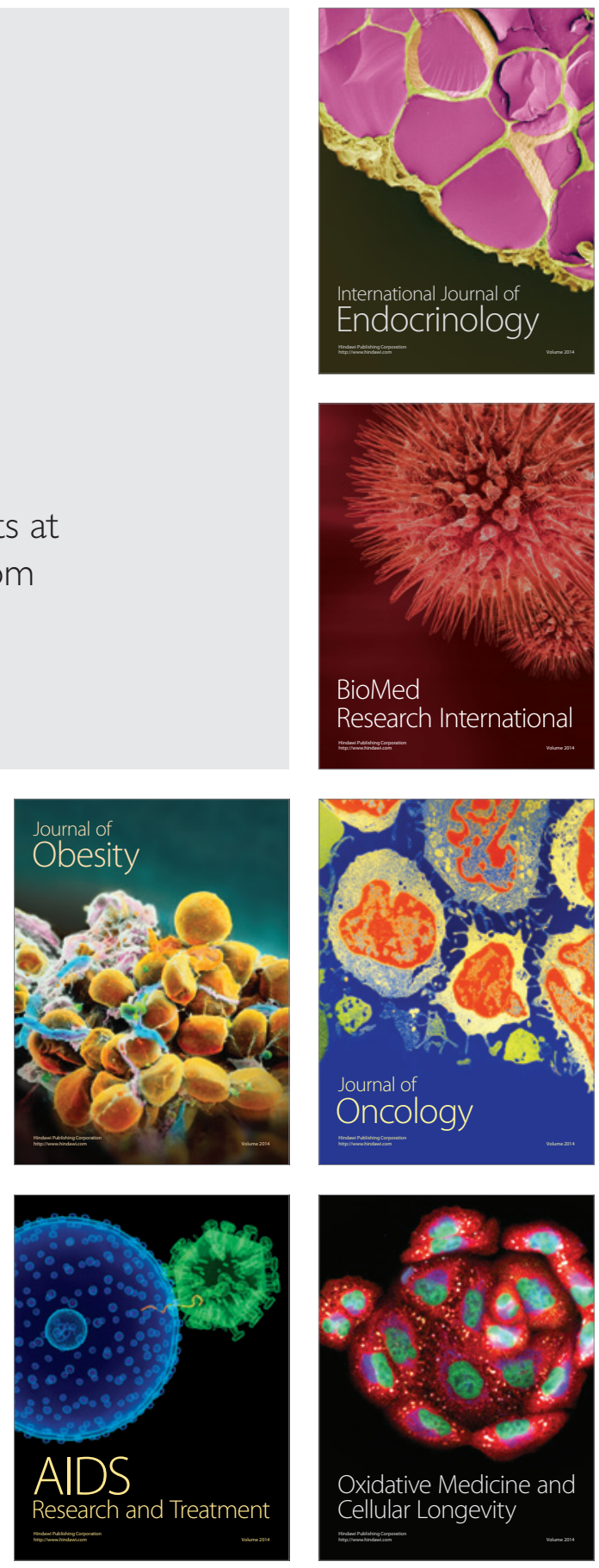